\title{
Predicting Vulnerabilities in the EU Banking Sector: The Role of Global and Domestic Factors*
}

\author{
Markus Behn, ${ }^{\mathrm{a}}$ Carsten Detken, ${ }^{\mathrm{a}}$ Tuomas Peltonen, ${ }^{\mathrm{b}}$ \\ and Willem Schudel ${ }^{\mathrm{c}}$ \\ ${ }^{a}$ European Central Bank \\ ${ }^{\mathrm{b}}$ European Systemic Risk Board \\ ${ }^{c}$ De Nederlandsche Bank
}

We estimate a multivariate early-warning model to assess the usefulness of private credit and other macrofinancial variables in predicting banking-sector vulnerabilities. Using data for twenty-three European countries, we find that global variables and in particular global credit growth are strong predictors of domestic vulnerabilities. Moreover, domestic credit variables also have high predictive power but should be complemented by other macrofinancial indicators such as house price growth and banking-sector capitalization that play a salient role in predicting vulnerabilities. Our findings can inform decisions on the activation of macroprudential policy measures and suggest that policymakers should take a broad approach in the analytical models that support risk identification and calibration of tools.

JEL Codes: G01, G21, G28.

*A previous version of the paper was titled "Setting Countercyclical Capital Buffers Based on Early-Warning Models-Would It Work?" (Behn et al. 2013). We would like to thank members of the ESRB Expert Group on Countercyclical Capital Buffers, as well as seminar participants at the European Central Bank, European Systemic Risk Board, the Banque de France Workshop on Countercyclical Capital Buffers on June 7, 2013 in Paris, and the 12th International Conference on Credit Risk Evaluation on September 26-27, 2013 in Venice for valuable comments and useful discussions. This paper is related to the comprehensive analysis conducted by the ESRB Expert Group on Countercyclical Capital Buffers. The views expressed are those of the authors and do not necessarily reflect those of the European Central Bank, the Eurosystem, De Nederlandsche Bank, or the European Systemic Risk Board. The usual disclaimer on errors applies here as well. Author e-mails: markus.behn@ecb.europa.eu; carsten.detken@ecb.europa.eu; tuomas.peltonen@esrb.europa.eu; c.j.w.schudel@dnb.nl. 


\section{Introduction}

Being faced with the longest and most severe financial crisis in decades, policymakers around the globe have actively searched for tools that could help to prevent or at least reduce the intensity of future financial crises. One such tool is the countercyclical capital buffer $(\mathrm{CCyB})$, which aims to address cyclical systemic risk and is an integral part of the Basel III regulations and the EU Capital Requirements Directive (CRD IV). To measure the level of cyclical systemic risk, the Basel III framework promotes a methodology based on the ratio of aggregate credit to GDP (Basel Committee on Banking Supervision 2010), which has consequently featured prominently in policy decisions around the globe. However, while credit growth and the credit-to-GDP ratio are clearly important determinants of cyclical systemic risk, there are a number of other factors that can also indicate a buildup of vulnerabilities, which provides the motivation for this paper.

We assess the usefulness of credit and other macrofinancial variables for the prediction of banking-sector vulnerabilities in a multivariate framework, hence enabling a more informed decision on the activation of the CCyB. The Basel Committee on Banking Supervision (BCBS) guidelines are based on an analysis that uses a sample of twenty-six countries from all over the world, for which the credit-toGDP gap (defined as the deviation of the credit-to-GDP ratio from its long-term trend) performs as the best single indicator in terms of signaling a coming financial crisis. However, the guidelines (or the underlying work by Drehmann, Borio, and Tsatsaronis 2011) rely on individual indicators and do not compare the predictive power of the credit-to-GDP gap to that of other potentially relevant variables related to risks to financial stability in a multivariate framework 1 Acknowledging the potentially very large implications that this policy has for the international banking sector, our paper aims to fill this

\footnotetext{
${ }^{1}$ Several other potential shortcomings of the credit-to-GDP gap have been discussed in the literature. For example, Edge and Meisenzahl (2011) argue that gap measures are sensitive to the exact specification of the trending variable, in particular with regards to end-of-sample estimates of the credit-to-GDP ratio. For other critical views on the reliability or suitability of the credit-to-GDP gap in the context of the CCyB, see for example Repullo and Saurina (2011) and Seidler and Gersl (2011).
} 
gap by estimating a multivariate early-warning model that includes private credit and other macrofinancial and banking-sector variables.

Our findings suggest that global variables and, in particular, global credit variables are strong predictors of macrofinancial vulnerabilities, providing good signals when used as single indicators and demonstrating consistent and significant effects in multivariate logit models. This concurs with the view that excessive global liquidity was one of the factors that contributed to the accumulation of financial vulnerabilities ahead of the global financial crisis (see, e.g., Committee on the Global Financial System 2011, International Monetary Fund 2013). The domestic credit-to-GDP gap also predicts vulnerabilities, although the effect is smaller than for the global credit variables. Despite the importance of credit variables, we also find evidence suggesting that other variables play a salient role in predicting vulnerable states of the economy. For example, domestic house price growth and global equity price growth are positively associated with macrofinancial vulnerabilities. Moreover, banking-sector variables exert significant effects: Strong banking-sector profitability may incur excessive risk-taking, leading to increased vulnerability, while a high banking-sector capitalization decreases the probability of entering a vulnerable state. This result is important for policymakers involved in setting the $\mathrm{CCyB}$, as it reinforces the notion that higher bank capital ratios reduce the likelihood of financial vulnerability.

The results illustrate that even though credit variables are essential ingredients of early-warning models, other macrofinancial and banking-sector variables are important covariates to control for and to improve the predictive power of these models. Moreover, in an increasingly integrated economy, vulnerabilities that develop at a global level potentially transmit to countries around the world and should hence be taken into account when determining $\mathrm{CCyB}$ rates. The Basel III/CRD IV framework accounts for this by ensuring that the institution-specific $\mathrm{CCyB}$ rate is calculated as a weighted average of $\mathrm{CCyB}$ rates in countries to which the bank has exposures. Overall, policymakers should take a broad approach in the analytical models that support decisions on the activation of tools instead of focusing only on the domestic credit-to-GDP gap.

Our paper adds to the literature on early-warning models for financial and banking crises (see Alessi et al. 2015 and Holopainen and Sarlin 2016 for recent papers conducting horse races among 
existing methods). It builds on the so-called signaling approach, originally developed by Kaminsky, Lizondo, and Reinhart (1998), and extended by Demirgüç-Kunt and Detragiache (2000), Alessi and Detken (2011), Lo Duca and Peltonen (2013), and Sarlin (2013), and features a multivariate logit model to identify vulnerabilities in the banking system (see, e.g., Barrell et al. 2010, Karim et al. 2013, and Babecky et al. 2014). As a traditional early-warning model, our approach rests on the translation of predicted crisis probabilities from the logit model into binary signals that can then be evaluated given policymakers' preferences between type I (missing a crisis) and type II errors (false alarms of crises). Other recent contributions to the early-warning literature have focused on exploiting different methodologies to extract early warning models (Alessi and Detken 2014, Ferrari and Pirovano 2015), characterizations of the financial cycle (Drehmann, Borio, and Tsatsaronis 2013; Schüler, Hiebert, and Peltonen 2015; Galati et al. 2016), or machine learning approaches (Schüler, Hiebert, and Peltonen 2015, 2017; Holopainen and Sarlin 2016). While previous studies using multivariate early-warning models often focused on emerging markets (e.g., Frankel and Rose 1996; Demirgüç-Kunt and Detragiache 1998, 2000; and Manasse, Savona, and Vezzoli 2016) or a few large economies or individual countries (e.g., Hanschel and Monnin 2005, Ito et al. 2014, Castro, Estrada, and Martínez-Pagés 2016), our analysis is conducted for a sample of twenty-three European Union (EU) member states spanning the period from 1982 to 2012, hence informing possible decisions on $\mathrm{CCyB}$ rates in EU countries.

The remainder of the paper is organized as follows: We present our data set in section 2 and introduce the methodology in section 3. Estimation results and robustness checks are presented in section 4, while section 5 is reserved for our concluding remarks.

\section{Data}

This section introduces the data used for our study. We begin with the identification of vulnerable states, i.e., the dependent variable in the study, based on banking crises in the European Union. We then proceed by introducing the independent variables used in the empirical analysis. Finally, we present some descriptive statistics on the development of key variables around banking-sector crises in the sample countries. 


\subsection{Definition of Vulnerable States}

The paper develops an early-warning model that attempts to predict vulnerable states of the economy from which - given a suitable trigger-banking crises could emerge. Thus, we are not trying to predict banking crises per se, even though we need to identify these crises in order to determine the vulnerable states. Specifically, we define a vulnerable state as the period twelve to seven quarters before the onset of a banking crisis. The time horizon accounts for the $\mathrm{CCyB}$ announcement period of twelve months that is specified in article 126(6) of the CRD IV, and for a time lag required to impose such a policy. At the same time, extending the horizon too far into the past may weaken the link between observed variation in the independent variables and the onset of banking crises. To analyze this, we provide a number of alternative time horizons in the robustness section.

In order to identify banking crises, we use the data set that has been compiled by Babecky et al. (2014) as part of a data collection exercise by the European System of Central Banks (ESCB) Heads of Research Group (labeled HoR database hereafter). This quarterly database contains information on banking crises in EU countries (except Croatia) between 1970:Q1 and 2012:Q4. The crisis index takes a value of 1 when a banking crisis occurred in a given quarter (and a value of 0 when no crisis occurred). The HoR database aggregates information on banking crises from "several influential papers," including (in alphabetical order): Caprio and Klingebiel (2003); Detragiache and Spilimbergo (2001); Kaminsky (2006); Kaminsky and Reinhart (1999); Laeven and Valencia (2008, 2010, 2012); Reinhart and Rogoff (2011, 2013); and Yeyati and Panizza (2011). The crisis indexes from these papers have subsequently been cross-checked with the ESCB Heads of Research before inclusion in the database. A list of the banking crisis dates for our sample countries based on this data set is provided in table 1. In the robustness section, we test the robustness of the results by regressing the benchmark model on banking crisis data provided by Reinhart and Rogoff (2011) and Laeven and Valencia (2012).

We set the dependent variable to 1 between (and including) seven to twelve quarters prior to a banking crisis as identified by the ESCB HoR database and to 0 for all other quarters in the data. In order to 
Table 1. Data Availability and Crisis Dates

\begin{tabular}{|c|c|c|c|}
\hline & $\begin{array}{c}\text { Credit } \\
\text { Variables }\end{array}$ & $\begin{array}{c}\text { Other } \\
\text { Variables }\end{array}$ & $\begin{array}{c}\text { HoR Banking } \\
\text { Crises }\end{array}$ \\
\hline Austria & 1982:Q1-2012:Q3 & 1986:Q4-2012:Q3 & 2008:Q4 \\
\hline Belgium & 1982:Q2-2012:Q3 & 1982:Q1-2012:Q3 & 2008:Q3-2008:Q4 \\
\hline Czech Republic & 1994:Q2-2012:Q2 & - & 1998:Q1-2002:Q2 \\
\hline Denmark & 1982:Q2-2012:Q3 & 1992:Q2-2012:Q3 & $\begin{array}{l}\text { 1987:Q1-1993:Q4, } \\
\text { 2008:Q3-end of } \\
\text { sample }\end{array}$ \\
\hline Estonia & 2005:Q1-2012:Q2 & 2005:Q2-2012:Q2 & - \\
\hline Finland & 1982:Q2-2012:Q3 & 1987:Q2-2012:Q3 & 1991:Q1-1995:Q4 \\
\hline France & 1982:Q2-2012:Q3 & 1992:Q2-2012:Q3 & $\begin{array}{l}\text { 1994:Q1-1995:Q4, } \\
\text { 2008:Q1-2009:Q4 }\end{array}$ \\
\hline Germany & 1982:Q2-2012:Q2 & 1991:Q2-2011:Q4 & 2008:Q1-2008:Q4 \\
\hline Greece & 2003:Q1-2012:Q2 & 2003:Q1-2012:Q2 & $\begin{array}{l}\text { 2008:Q1-end of } \\
\text { sample }\end{array}$ \\
\hline Hungary & 1997:Q1-2012:Q3 & 2002:Q1-2012:Q2 & 2008:Q3-2009:Q4 \\
\hline Ireland & 1999:Q1-2012:Q3 & 1999:Q1-2010:Q4 & $\begin{array}{c}\text { 2008:Q1-end of } \\
\text { sample }\end{array}$ \\
\hline Italy & 1982:Q2-2012:Q3 & 1990:Q3-2012:Q2 & 1994:Q1-1995:Q4 \\
\hline Lithuania & 2005:Q1-2012:Q2 & 2005:Q1-2012:Q2 & 2009:Q1-2009:Q4 \\
\hline Luxembourg & 2004:Q2-2012:Q3 & 2004:Q2-2010:Q4 & $\begin{array}{l}\text { 2008:Q2-end of } \\
\text { sample }\end{array}$ \\
\hline Malta & 2006:Q2-2012:Q2 & - & - \\
\hline Netherlands & 1982:Q2-2012:Q2 & 1982:Q1-2011:Q4 & 2008:Q1-2008:Q4 \\
\hline Poland & 1997:Q1-2012:Q3 & 2003:Q1-2012:Q3 & - \\
\hline Portugal & 1982:Q2-2011:Q4 & 1998:Q2-2011:Q4 & - \\
\hline Slovakia & 2005:Q2-2012:Q2 & - & - \\
\hline Slovenia & 2005:Q3-2012:Q2 & - & - \\
\hline Spain & 1982:Q2-2012:Q3 & 1995:Q2-2012:Q3 & 1982:Q2-1985:Q3 \\
\hline Sweden & 1982:Q2-2012:Q3 & 1986:Q2-2012:Q3 & $\begin{array}{l}\text { 1990:Q3-1993:Q4, } \\
\text { 2008:Q3-2008:Q4 }\end{array}$ \\
\hline United Kingdom & 1982:Q2-2012:Q3 & 1988:Q2-2012:Q2 & $\begin{array}{l}\text { 1991:Q1-1995:Q2, } \\
\text { 2007:Q1-2007:Q4 }\end{array}$ \\
\hline \multicolumn{4}{|c|}{$\begin{array}{l}\text { Notes: The table shows the availability of credit and other variables as well as } \\
\text { the crisis dates for the twenty-three countries in our sample. Credit variables are } \\
\text { obtained from the BIS database for total credit to the private non-financial sec- } \\
\text { tor (see Dembiermont, Drehmann, and Muksakunratama 2013) and from Eurostat } \\
\text { for those countries where the BIS data are not available. Other macrofinancial and } \\
\text { banking-sector variables are obtained from various sources, including the BIS, IMF, } \\
\text { and OECD. The crisis definitions are from the ESCB Heads of Research database } \\
\text { described in Babecky et al. (2014). }\end{array}$} \\
\hline
\end{tabular}


overcome crisis and post-crisis bias (see, e.g., Bussière and Fratzscher 2006), we omit all country quarters that either witnessed a banking crisis or that fall within six quarters after a banking crisis.

\subsection{Macrofinancial and Banking-Sector Variables}

The panel data set used in the analysis contains quarterly macrofinancial and banking-sector data spanning 1982:Q2-2012:Q3 for twenty-three EU member states. The data is sourced through Haver Analytics and originally comes from the Bank for International Settlements (BIS), Eurostat, the International Monetary Fund (IMF), the European Central Bank (ECB), and the OECD (see the appendix for a detailed description). Table 1 provides an overview of the data availability for our main variables, while table 2 gives descriptive statistics for the variables included in our study.

Accelerated credit growth is one of the key variables in the Basel III/CRD IV framework, as it is seen as a sign of overheating that may be associated with systemic events in the banking sector (see also, e.g., Schularick and Taylor 2012, Drehmann and Juselius 2014, or López-Salido, Stein, and Zakrajšek 2016). To measure credit growth and levels, we follow Drehmann, Borio, and Tsatsaronis (2011) and use the long series on total credit and domestic bank credit to the private non-financial sector compiled by the BIS. This data includes borrowing from non-financial corporations, households, and non-profit institutions serving households. It aims to capture all sources of lending, independent of the country of origin or type of lender, and includes loans and debt securities such as bonds and securitized loans (see Dembiermont, Drehmann, and Muksakunratana 2013 for a description of the database). To our knowledge, the BIS credit series offers the broadest definition of credit provision to the private sector, while having been adjusted for data gaps and structural breaks. Our models account for credit growth and leverage, both at the domestic and at the global level. Credit growth is measured as a percentage (annual growth), while leverage is measured by the deviation of the credit-to-GDP ratio (using nominal GDP data) from its long-term backward-looking trend (see the appendix for details on the calculation). Global credit variables have been computed using a GDP-weighted average of the variable in question for several countries, including the United States, Japan, 
Table 2. Descriptive Statistics

\begin{tabular}{|c|c|c|c|c|c|}
\hline & Obs. & Mean & Std. Dev. & Min. & Max. \\
\hline Dom. Credit Growth (qoq) & 1,220 & 0.0228 & 0.0196 & -0.0318 & 0.0989 \\
\hline Dom. Credit Growth (yoy) & 1,220 & 0.0926 & 0.0662 & -0.0690 & 0.3579 \\
\hline Dom. Credit Gap & 1,220 & 0.1149 & 0.1186 & -0.1570 & 0.4550 \\
\hline Dom Credit Growth (4q MA) & 1,220 & 0.0232 & 0.0166 & -0.0173 & 0.0897 \\
\hline Dom. Credit Growth (6q MA) & 1,220 & 0.0232 & 0.0154 & -0.0122 & 0.0813 \\
\hline Dom. Credit Growth (8q MA) & 1,220 & 0.0233 & 0.0150 & -0.0099 & 0.0805 \\
\hline Dom. Credit-to-GDP Ratio & 1,220 & 1.2756 & 0.4259 & 0.4426 & 2.4829 \\
\hline Dom. Credit-to-GDP Gap & 1,220 & 0.0346 & 0.0796 & -0.1788 & 0.3249 \\
\hline $\begin{array}{l}\text { Dom. Credit Growth - GDP } \\
\text { Growth }\end{array}$ & 1,220 & 0.0081 & 0.0171 & -0.0508 & 0.0715 \\
\hline Glo. Credit Growth (qoq) & 1,220 & 0.0152 & 0.0086 & -0.0048 & 0.0335 \\
\hline Glo. Credit Growth (yoy) & 1,220 & 0.0614 & 0.0289 & -0.0113 & 0.1095 \\
\hline Glo. Credit Gap & 1,220 & 0.0597 & 0.0431 & -0.0101 & 0.1593 \\
\hline Glo. Credit Growth (4q MA) & 1,220 & 0.0154 & 0.0071 & -0.0028 & 0.0274 \\
\hline Glo. Credit Growth (6q MA) & 1,220 & 0.0156 & 0.0069 & -0.0021 & 0.0280 \\
\hline Glo. Credit Growth (8q MA) & 1,220 & 0.0158 & 0.0065 & 0.0005 & 0.0274 \\
\hline Glo. Credit-to-GDP Ratio & 1,220 & 0.7557 & 0.1193 & 0.5778 & 0.9933 \\
\hline Glo. Credit-to-GDP Gap & 1,220 & 0.0158 & 0.0285 & -0.0420 & 0.0676 \\
\hline $\begin{array}{l}\text { Glo. Credit Growth - Glo. } \\
\text { GDP Growth }\end{array}$ & 1,220 & 0.0022 & 0.0235 & -0.0492 & 0.0671 \\
\hline GDP Growth & 919 & 0.0123 & 0.0088 & -0.0232 & 0.0437 \\
\hline Inflation & 919 & 0.0242 & 0.0166 & -0.0108 & 0.1078 \\
\hline Equity Price Growth & 919 & 0.0240 & 0.1199 & -0.3759 & 0.3051 \\
\hline House Price Growth & 919 & 0.0172 & 0.0289 & -0.0735 & 0.1204 \\
\hline Banking-Sector Capitalization & 756 & 0.0507 & 0.0161 & 0.0238 & 0.1088 \\
\hline Banking-Sector Profitability & 756 & 0.0066 & 0.0040 & -0.0142 & 0.0292 \\
\hline Gov. Bond Yield & 862 & 0.0575 & 0.0237 & 0.0220 & 0.1385 \\
\hline Money Market Rate & 862 & 0.0460 & 0.0292 & 0.0010 & 0.1643 \\
\hline Global GDP Growth & 919 & 0.0117 & 0.0229 & -0.0585 & 0.0616 \\
\hline Global Equity Price Growth & 919 & 0.0135 & 0.0675 & -0.3344 & 0.1122 \\
\hline Global House Price Growth & 919 & 0.0066 & 0.0162 & -0.0389 & 0.0539 \\
\hline \multicolumn{6}{|c|}{$\begin{array}{l}\text { Notes: The table shows descriptive statistics for the credit variables and the other } \\
\text { macrofinancial indicators used in the empirical analysis. Credit variables are available } \\
\text { for a longer period of time in most countries, which is why the number of observations } \\
\text { is larger for them. }\end{array}$} \\
\hline
\end{tabular}


Canada, and all European countries that are in this study (see also Alessi and Detken 2011).

In order to test the importance of credit variables in a comparative fashion as well as to analyze the potential importance of other factors, we include a number of additional variables in our study. These variables are available for fewer observations than the credit variables, which is why the number of observations in the full model differs from the number of observations in models that include only credit variables (estimating credit models on the reduced sample yields results that are very similar to the ones for the full sample). To account for the macroeconomic environment and monetary stance, we include nominal GDP growth (domestic and global) and CPI inflation rates. Furthermore, we use data on annual equity and residential house price growth, both domestically and globally, to account for the common view that asset price booms can be associated with a buildup of vulnerabilities in the banking sector (see, e.g., Allen and Gale 2009, Brunnermeier and Oehmke 2013, or Jordà, Schularick, and Taylor 2015). Finally, to control for banking-sector profitability and solvency, we include aggregate bank capitalization (calculated by the ratio of equity over total assets) and aggregate banking-sector profitability (defined as net income before tax as a percentage of total assets).

As we are estimating binary choice models using panel data, non-stationarity of independent variables could be an issue (Park and Phillips 2000). We perform panel unit-root tests suggested by Im, Pesaran, and Shin (2003) as well as univariate unit-root tests developed by Dickey and Fuller (1979) in order to analyze the timeseries properties of the variables of interest. In the panel unit-root test, the null hypothesis that all cross-sections contain unit roots can be rejected at least at the 10 percent level of confidence for all series except for the credit-to-GDP gap and global credit growth. We complement the panel unit-root analysis by using the Dickey and Fuller (1979) test country by country, and can reject the null hypothesis of a unit root for the credit-to-GDP gap at least at the 10 percent level for all countries except for Estonia, Lithuania, and Greece. Furthermore, in the country-by-country unit-root tests, we can reject the null hypothesis for the global credit-to-GDP gap at least at the 10 percent level for all countries except for Estonia and Lithuania, while for global credit growth the null hypothesis can be rejected for all countries. This implies that sample periods for 
individual countries seem to affect unit-root test results. Overall, the transformations done to the original variables, the results from the unit-root tests, and general economic theory make us confident that we have addressed potential non-stationarity concerns for the variables of interest.

\subsection{Development of the Key Variables}

Before entering the discussion of the main results, we shortly present some descriptive statistics, which provide the context of our main argument of moving beyond credit variables when predicting macrofinancial vulnerabilities. Figure 1 presents the average development of the six main variables of interest over time before and after the onset of a banking crisis. For the purpose of predicting crises, one would hope to find an indicator variable that (on average) peaks (or bottoms out, or at least changes direction) a number of quarters before a crisis, so that it can be used as a signal. In the current case of predicting a vulnerable state of the economy that precedes a potential banking crisis, we would be interested in variables that change direction a bit earlier before the onset of a crisis (i.e., two to three years before the crisis), so that policymakers can use this time to increase the resilience of banks.

In this context, we observe that among the six variables depicted here, the credit-to-GDP gap shows one of the least clear pictures in terms of signaling a coming crisis. On average, the credit gap increases slowly prior to a banking crisis and only starts falling about one year into the crisis. Yet, this does not need to be a very surprising development, as this variable is a ratio and therefore requires the numerator to grow more slowly (or decrease faster) than the denominator in order for the variable to decrease in value. The BCBS itself concedes that the credit-to-GDP trend may not capture turning points well (Basel Committee on Banking Supervision 2010). Consequently, the ratio will not fall unless credit falls faster than GDP, something that is not at all certain during banking crises. Still, it shows that purely from a descriptive perspective, any signal derived from the credit gap needs to come from the level of this variable (i.e., a threshold value), not from changes in its development.

Unlike the credit gap, credit growth (as depicted in percentage year-on-year growth) does appear to hit a peak about two years 


\section{Figure 1. Development of Key Variables around Banking Crises}
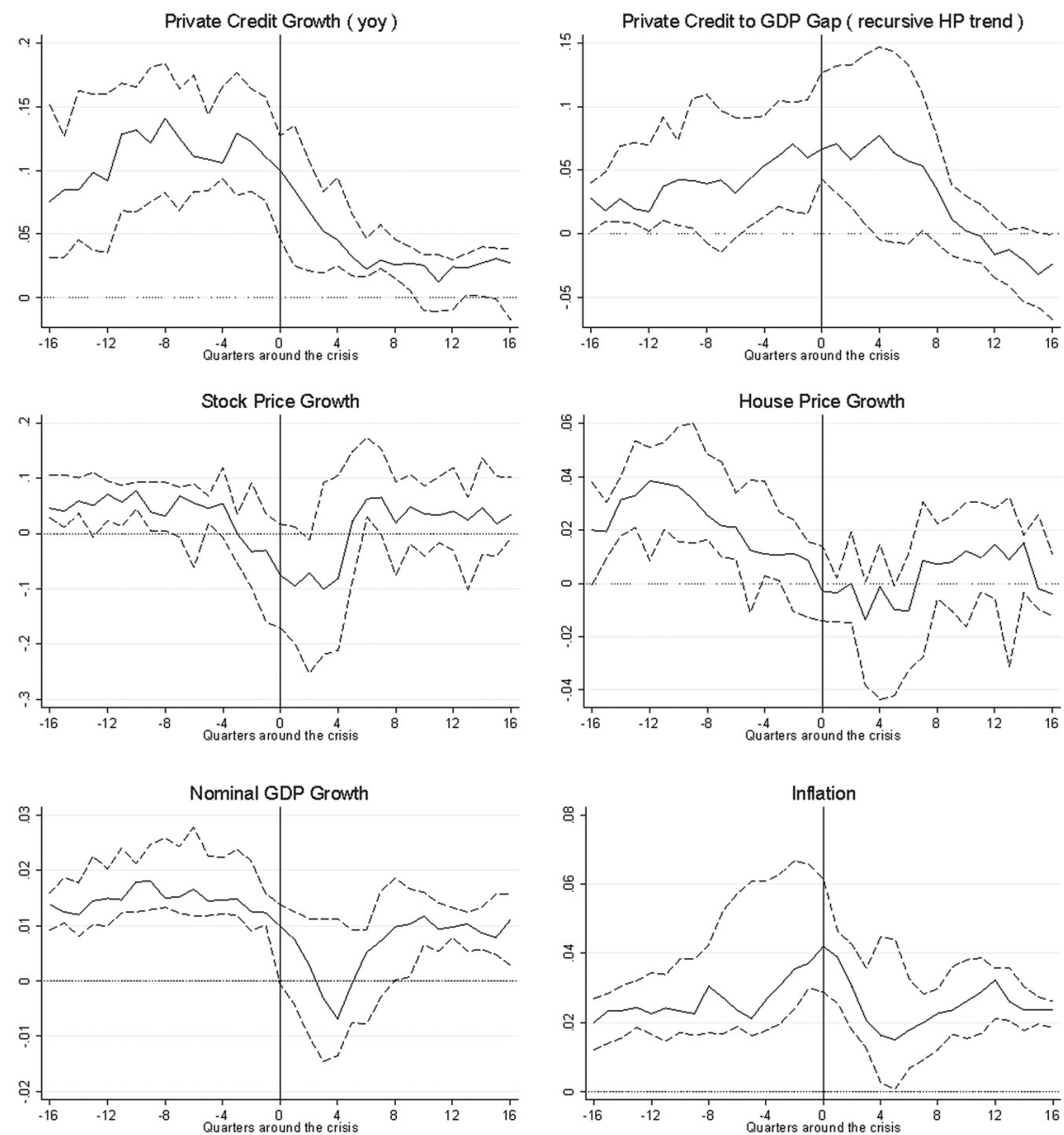

Notes: The figure depicts the development of selected key variables around banking crises within the sample countries. The start date of a banking crisis is indicated by the vertical line, while the solid line shows the development in the median country and the dashed lines represent the countries at the 25 th and 75 th percentile, respectively.

before the onset of a banking crisis, even though its fall only becomes clear during the last pre-crisis year. A similar development can be observed in nominal GDP growth and equity price growth figures. These variables do peak before a crisis (on average), but the signal 
that a crisis is coming only becomes evident shortly before the crisis happens. This makes it difficult, at least from a descriptive point of view, to extract any strong signal from these variables. By some margin, residential house price growth outperforms the other domestic variables in terms of signaling "power" in this descriptive exercise. In our sample, the growth rate of residential house prices tends to peak about three years before a crisis happens on average, starting a clear descent (although prices are still rising) that lasts into the crisis where growth stalls. Based on this evidence, we would conclude that residential house prices would be a useful tool (at least much more useful than the other variables shown here) for decisions on the $\mathrm{CCyB}$, as it clearly fulfills the early-warning requirement (one year of implementation plus one or two quarters of publication lag). So, at least from a descriptive standpoint, it is clear that it makes sense to gauge the developments of different macrofinancial variables to predict or signal coming crises. Whether this result holds in a more rigorous comparative (multivariate) framework will be discussed in the subsequent analysis.

\section{Methodology}

In this section we introduce the methodology used in the empirical analysis. We start by introducing the logistic regressions used in our multivariate framework. Thereafter, we explain how we evaluate individual indicators' and model predictions' usefulness for policymakers.

\subsection{Multivariate Models}

In order to assess the predictive abilities of credit, macrofinancial, and banking-sector variables in a multivariate framework, we estimate logistic regressions of the following form:

$$
\operatorname{Prob}\left(y_{i t}=1\right)=\frac{e^{\alpha_{i}+X_{i t}^{\prime} \beta}}{1+e^{\alpha_{i}+X_{i t}^{\prime} \beta}},
$$

where $\operatorname{Prob}\left(y_{i t}=1\right)$ denotes the probability that country $i$ is in a vulnerable state, where a banking crisis could occur seven to twelve quarters ahead of quarter $t$. As independent variables, the vector 
$X_{i t}$ includes credit and macrofinancial variables on the domestic and on the global level as well as domestic banking-sector variables (see section 2.2). The estimations also include country fixed effects, $\alpha_{i}$, in order to account for unobserved heterogeneity at the country level. 2 Finally, we use robust standard errors clustered at the quarterly level in order to account for potential correlation in the error terms that might arise from the fact that global variables are identical across countries in a given quarter 3

The analysis is conducted as much as possible in a real-time fashion, meaning that only information that is available at a particular point in time is used. Therefore, all detrended variables have been calculated using backward-looking trends, and all explanatory variables have been lagged by one quarter, also to account for possible endogeneity. We are well aware that this simple procedure cannot crowd out all endogeneity-related bias, but we note that the dependent variable itself is an early-warning variable. The time horizon for which this variable is equal to 1 has been chosen in the context of our exercise and has not been exogenously determined. Therefore, we consider endogeneity to be a somewhat smaller problem in this study. Nevertheless, we have tested our models for different specifications of the dependent variable, both in terms of the pre-crisis period chosen (one to twelve/thirteen to twenty quarters before the onset of a crisis) and the definition and data source of banking crises in the robustness section.

\subsection{Model Evaluation}

Banking crises are (thankfully) rare events in the sense that most EU countries have encountered none or only one over the past two decades. Still, when they occur, banking crises tend to be very costly,

\footnotetext{
${ }^{2}$ We do not include time dummies for two reasons: First, only quarters where at least one country experiences a banking crisis could be used for identification in such a specification. As our sample includes many quarters where none of the countries experienced a crisis, the inclusion of time dummies would significantly reduce the sample size. Second, the focus in our paper is on the prediction of future banking crises. While time dummies might improve the ex post fit of a model, they are of little use for out-of-sample forecasting since they are not known ex ante.

${ }^{3}$ Clustering at the country level yields smaller standard errors, in particular for the global variables.
} 
both directly through bailouts and fiscal interventions and indirectly through the loss of economic output that often tends to follow these crises (in particular, for systemic banking crises). Thus, policymakers have a clear incentive to be able to detect early enough potential signs of vulnerabilities that might precede banking crises in order to take measures to prevent further building up of vulnerabilities or to strengthen the resilience of the banking sector. Yet, at the same time, policymakers may not want to be signaling crises when in fact they do not happen afterwards. Doing so may (i) reduce the credibility of their signals, weakening decisionmaking and damaging their reputation, and (ii) needlessly impose costs on the banking sector, endangering credit supply. As a consequence, policymakers also have an incentive to avoid false alarms, i.e., they do not want to issue warnings when a crisis is not imminent. As pointed out by Alessi and Detken (2011), an evaluation framework for an early-warning model needs to take into account policymakers' relative aversion with respect to type I errors (not issuing a signal when a crisis is imminent) and type II errors (issuing a signal when no crisis is imminent).

The evaluation approach in this paper is based on the so-called signaling approach that was originally developed by Kaminsky, Lizondo, and Reinhart (1998) and extended by Demirgüç-Kunt and Detragiache (2000), Alessi and Detken (2011), Lo Duca and Peltonen (2013), and Sarlin (2013). In this framework, an indicator issues a warning signal whenever its value in a certain period exceeds a threshold $\tau$, defined by a percentile of the indicator's country-specific distribution. Similarly, a multivariate probability model issues a warning signal whenever the predicted probability from this model exceeds a threshold $\tau \in[0,1]$, again defined as a percentile of the country-specific distribution of predicted probabilities. In this way, individual variables and model predictions for each observation $j$ are transformed into binary predictions $P_{j}$ that are equal to 1 if the respective thresholds are exceeded for this observation and 0 otherwise. Predictive abilities can then be evaluated by comparing the signals issued by the respective variable or model with the actual outcome $C_{j}$ for each observation. Each observation can be allocated to one of the quadrants in the contingency matrix depicted in figure 2 : A period with a signal by a specific indicator can either be followed by a banking crisis seven to twelve quarters ahead (TP) or not (FP). Similarly, a period without a signal can be followed by a banking 


\section{Figure 2. Contingency Matrix}

\begin{tabular}{|c|c|c|c|}
\hline & \multicolumn{2}{|c|}{ Actual class $C_{i t}$} \\
\hline & & 1 & 0 \\
\hline $\begin{array}{l}\tilde{5} \\
\text { v } \\
\text { w }\end{array}$ & 1 & $\begin{array}{l}\text { True positive } \\
\text { (TP) }\end{array}$ & $\begin{array}{l}\text { False positive } \\
\text { (FP) }\end{array}$ \\
\hline (1) & 0 & $\begin{array}{l}\text { False negative } \\
\text { (FN) }\end{array}$ & $\begin{array}{l}\text { True negative } \\
\text { (TN) }\end{array}$ \\
\hline
\end{tabular}

Notes: The figure shows the relationship between model prediction and actual outcomes. Observations are classified into those where the indicator issues a warning that is indeed followed by a banking crisis seven to twelve quarters ahead (TP), those where the indicator issues a warning that is not followed by a crisis $(\mathrm{FP})$, those where the indicator issues no warning and there is no crisis seven to twelve quarters ahead (TN), and those where the indicator issues no warning although there is a crisis coming $(\mathrm{FN})$.

crisis seven to twelve quarters ahead $(\mathrm{FN})$ or not $(\mathrm{TN})$. Importantly, the number of observations classified into each category depends on the threshold $\tau$.

In order to obtain the optimal threshold $\tau$, one needs to take the policymaker's preferences vis-à-vis type I errors (missing a crisis, $\left.T_{1}(\tau)=F N /(T P+F N) \in[0,1]\right)$ and type II errors (issuing a false alarm, $\left.T_{2}(\tau)=F P /(F P+T N) \in[0,1]\right)$ into account. This can be done by defining a loss function that depends on the two types of errors as well as the policymaker's relative preference for either type. The optimal threshold is then the one that minimizes the loss function. Taking into account the relative frequencies of crises $P_{1}=P\left(C_{j}=1\right)$ and tranquil periods $P_{2}=P\left(C_{j}=0\right)$, the loss function is defined as follows:

$$
L(\mu, \tau)=\mu P_{1} T_{1}(\tau)+(1-\mu) P_{2} T_{2}(\tau),
$$

where $\mu \in[0,1]$ denotes the policymakers' relative preference between type I and type II errors. A $\mu$ larger than 0.5 indicates that the policymaker is more averse to missing a crisis than to issuing a false alarm, which - in particular, following the recent financial crisis - is a realistic assumption in our view.

Using the loss function $L(\mu, \tau)$, the usefulness of a model can be defined in two ways. First, following the idea of Alessi and Detken 
(2011) and as in Sarlin (2013), the absolute usefulness is defined as

$$
U_{a}=\min \left(\mu P_{1},(1-\mu) P_{2}\right)-L(\mu, \tau) .
$$

Note that $U_{a}$ computes the extent to which having the model is better than having no model. This is because a policymaker can always achieve a loss of $\min \left(\mu P_{1},(1-\mu) P_{2}\right)$ by either always issuing a signal (in which case $T_{1}(\tau)=0$ ) or never issuing a signal (in which case $T_{2}(\tau)=0$ ). The fact that $P_{1}$ is significantly smaller than $P_{2}$ in our sample (the share of observations that is followed by a banking crisis seven to twelve quarters ahead is approximately 10 percent) implies that, in order to achieve a high usefulness of the model, a policymaker needs to be more concerned about the detection of vulnerable states potentially preceding banking crises than the avoidance of false alarms. Otherwise, with a suboptimal performing model, it would easily pay off for the policymaker to never issue a signal given the distribution of vulnerable states and tranquil periods (see Sarlin 2013 for a detailed discussion of this issue).

A second measure, the relative usefulness $U_{r}$, is computed as follows (see Sarlin 2013):

$$
U_{r}=\frac{U_{a}}{\min \left(\mu P_{1},(1-\mu) P_{2}\right)} .
$$

The relative usefulness $U_{r}$ reports $U_{a}$ as a percentage of the usefulness that a policymaker would gain from a perfectly performing model 4 The relative usefulness is our preferred performance indicator, as it allows the comparison of models for policymakers with different values for the preference parameter $\mu .5$

\section{Empirical Results}

In this section we present the empirical results. We first explore the usefulness of credit variables for the identification of vulnerable

\footnotetext{
${ }^{4}$ A perfectly performing indicator would have $T_{1}=T_{2}=0$, implying $L=0$ and $U_{a}=\min \left(\mu P_{1},(1-\mu) P_{2}\right)$.

${ }^{5}$ We also employ receiver operating characteristics (ROC) curves and the area under the ROC curve (AUROC) for comparing performance of the early-warning models (see the appendix for details).
} 
states of the banking sector, and proceed by extending the framework to a multivariate model including other macrofinancial and banking-sector indicators. Thereafter, we evaluate the out-of-sample performance of the estimated models and-finally-present some robustness checks.

\subsection{Estimation and Evaluation}

As the CRD IV regulations emphasize the role of credit variables for setting the countercyclical capital buffer rate - in particular, the role of credit growth and the credit-to-GDP gap — we start by evaluating the usefulness of these variables for the identification of vulnerable states within the EU banking sector.

\subsubsection{Individual Indicators Based on Credit Growth and Credit-to-GDP Ratios}

First, we evaluate the usefulness of domestic credit variables by using a simple signaling approach. Using a preference parameter of $\mu$ equal to 0.9 , panel A of table 3 reports the optimal threshold for several credit variable indicators 6 Given the optimal threshold, the table also shows the number of observations in each quadrant of the matrix depicted in figure 2; the percentage of type I and type II errors; and several performance measures, such as the absolute and the relative usefulness, the adjusted noise-to-signal (aNtS) ratio, 7 the percentage of vulnerable states correctly predicted by the indicator (\% Predicted), the probability of a vulnerable state conditional

\footnotetext{
${ }^{6} \mathrm{~A}$ preference parameter of $\mu$ equal to 0.9 indicates a strong preference for the detection of crises by the policymaker. In our view this is a reasonable assumption, as the current crisis illustrated once more that financial crises often translate into large costs for the economy. As Sarlin (2013) points out, using a $\mu$ equal to 0.9 and simultaneously taking into account the unconditional probability of a crisis (which is about 10 percent in our sample) is equivalent to using a $\mu$ equal to 0.5 without adjusting for the unconditional probabilities (as in Alessi and Detken 2011 or Lo Duca and Peltonen 2013). Results for different values of $\mu$ are available upon request.

${ }^{7}$ The aNtS ratio is the ratio of false signals measured as a proportion of quarters where false signals could have been issued to good signals as a proportion of quarters where good signals could have been issued, or $(F P /(F P+$ $T N)) /(T P /(T P+F N))$. A lower aNtS ratio indicates better predictive abilities of the model.
} 


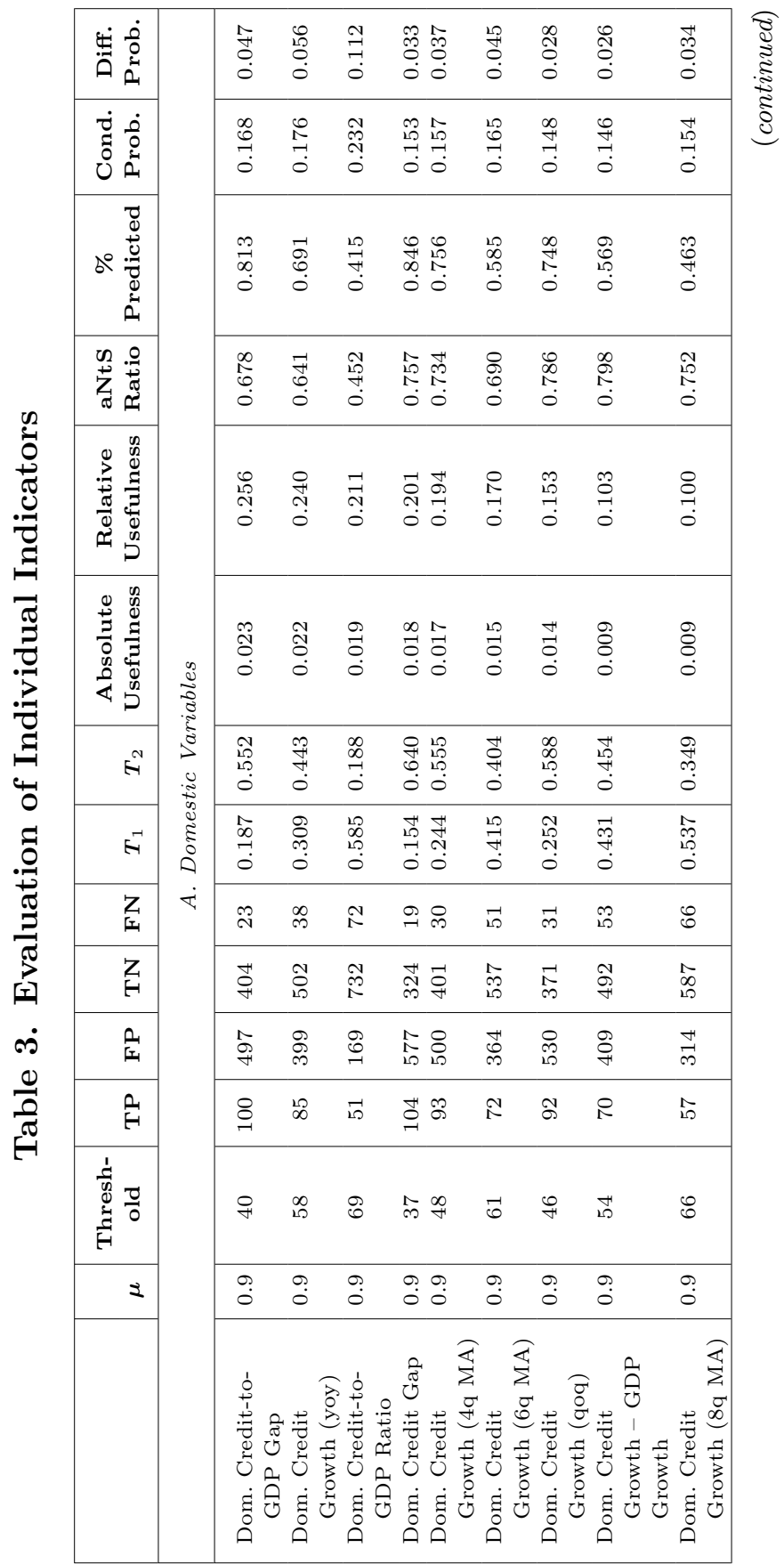




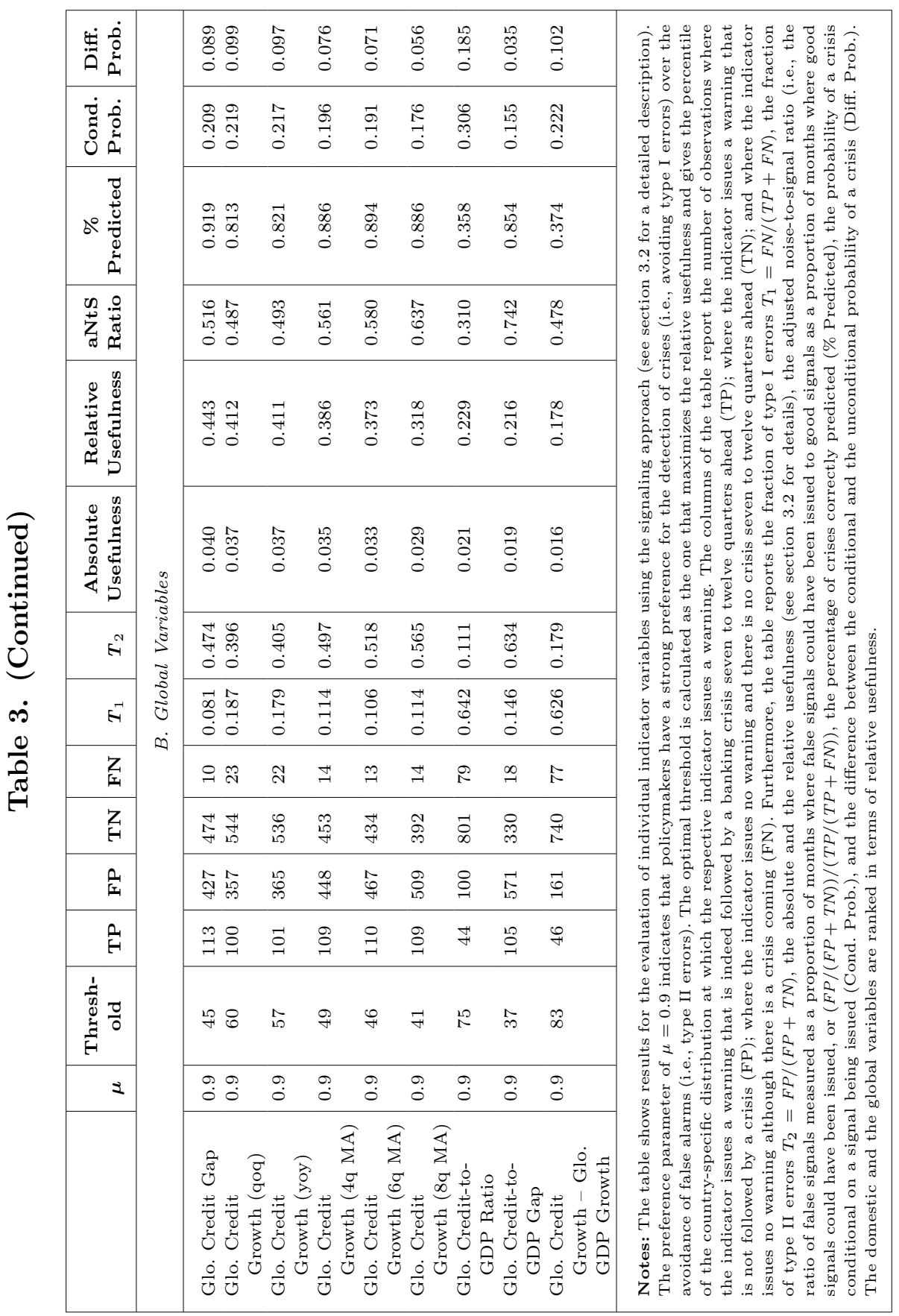


on a signal being issued (Cond. Prob.), and the difference between the conditional and the unconditional probability of a vulnerable state (Diff. Prob.).

Among the domestic indicators, indeed, the credit-to-GDP gap performs best in the sense that it generates the highest relative usefulness. This is consistent with findings by Drehmann, Borio, and Tsatsaronis (2011) for a different set of countries and in line with the approach taken in the Basel III/ CRD IV framework. The creditto-GDP gap issues a warning signal whenever it is above the 40th percentile of its country-specific distribution and achieves 25.6 percent of the usefulness a policymaker would gain from a perfectly performing model. Other transformations of the credit variables that perform relatively well are annual credit growth, the credit-to-GDP ratio, and the credit gap (defined as the deviation of the stock of credit from its long-term trend).

Interestingly, global credit variables seem to outperform domestic credit variables in terms of usefulness for predicting vulnerabilities in the domestic banking sector. Panel B of table 3 shows that these indicators usually exert a higher relative usefulness, exert a lower adjusted noise-to-signal ratio, and are able to predict a larger share of the vulnerable states in our sample. In an increasingly integrated economy, vulnerabilities that develop at a global level potentially transmit to countries around the world. Hence, focusing on the development of domestic credit variables might not be sufficient, and the calibration of $\mathrm{CCyB}$ rates should also account for global developments. This reasoning is, to some extent, already reflected in the Basel III/CRD IV framework, as the institution-specific CCyB rate is calculated as a weighted average of $\mathrm{CCyB}$ rates in countries to which the bank has exposures.

The evaluation of the predictive abilities of global variables is subject to a caveat: As these variables do not vary across countries, and as most countries had a crisis starting in 2008, the good performance of these variables can in part be explained by a clustering of crisis episodes within the same year. That is, indicators based on global credit variables correctly predicted the current crisis in several of our sample countries, which puts the higher usefulness of global as compared with domestic variables in a perspective. However, the current crisis is certainly one of the best examples of a non-domestic vulnerability that spread to banking systems around 
the world. Thus, if the aim of the $\mathrm{CCyB}$ is to increase the resilience of the banking system, it appears to be beneficial to take into account both domestic and global developments.

\subsubsection{Multivariate Models Including Other Macrofinancial Indicators}

While the signaling approach is a simple and useful way to assess the predictive abilities of individual indicators, a multivariate framework has the advantage of being able to assess the joint performance of several indicators. We therefore estimate simple logit models including several of the individual credit variables as well as other macrofinancial indicators and assess their performance and usefulness.

Results for these models are presented in table 4. Again, we start by considering only the domestic variables and focus on credit growth and the credit-to-GDP gap, as these variables performed well in section 4.1.1 and play a prominent role in the Basel III/CRD IV framework. Credit growth seems to dominate the credit-to-GDP gap, which is statistically not significant, in this simple model. Next, we gradually include the global credit variables, interactions between growth and leverage on the domestic and the global level as well as interactions between the domestic and the global variables 8 The predictive power of the model improves with each step 9

\footnotetext{
${ }^{8} \mathrm{We}$ orthogonalize interaction terms with first-order predictors in order to avoid problems of multicollinearity (see, e.g., Little, Bovaird, and Widaman 2006). In particular, when interacting two variables $X$ and $Y$, we first form the simple product $X \times Y$ and then regress it on the original variables: $X \times Y=$ $\alpha+\beta_{1} \times X+\beta_{2} \times Y+\epsilon$. We then take the residual from this regression- $\epsilon$, which is orthogonal to $X$ and $Y$ - to represent the interaction between the two original variables. Variance inflation factors (VIFs) smaller than ten for all variables indicate that we are able to get rid of multicollinearity problems in this way.

${ }^{9}$ Note that the interpretation of interaction effects in logit models is cumbersome. As pointed out by Ai and Norton (2003), the interaction effect is conditional on the independent variables (unlike interaction effects in linear models) and may have different signs for different values of the covariates. Moreover, the statistical significance of these effects cannot be evaluated with a simple t-test, but should be evaluated for each observation separately. Doing so allows us to conclude that for most observations only the Interaction(GC1 $\times$ GC2) is significantly positive, while the other interactions are insignificant (although, e.g., the Interaction $(\mathrm{DC} 2 \times \mathrm{GC} 2)$ has a significantly negative sign in the regression itself).
} 


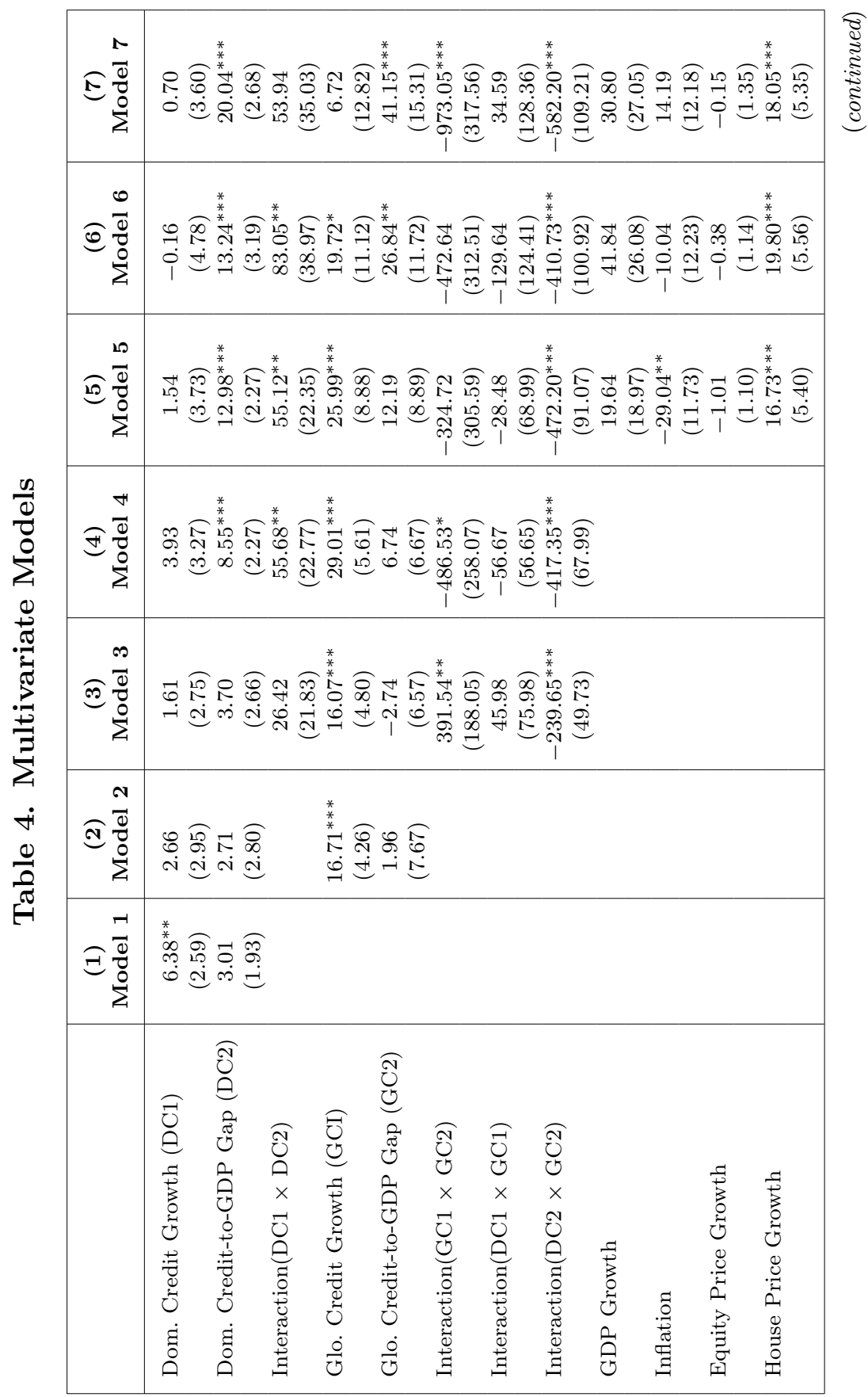




\begin{tabular}{|c|c|c|c|c|c|c|}
\hline \multirow{2}{*}{ 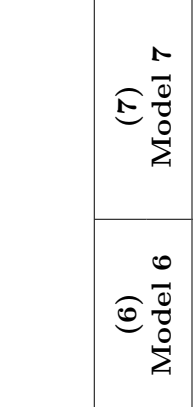 } & \multicolumn{5}{|c|}{ 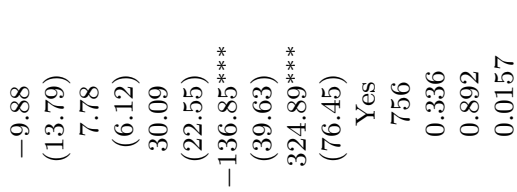 } & \multirow{8}{*}{ 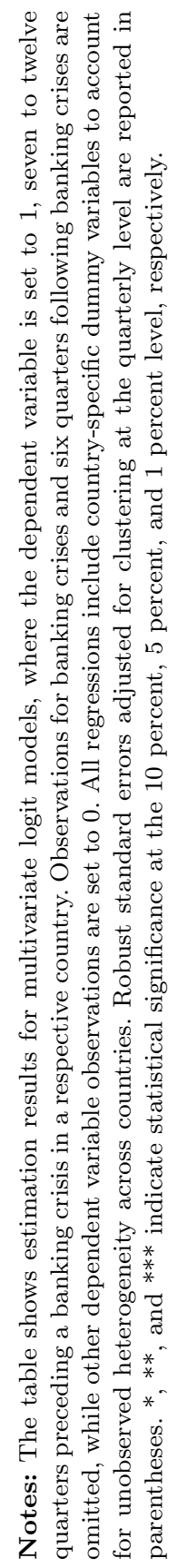 } \\
\hline & \multicolumn{5}{|c|}{ 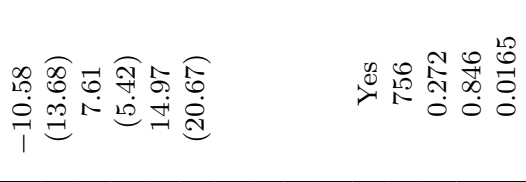 } & \\
\hline $2 \frac{10}{20}$ & \multicolumn{5}{|c|}{ 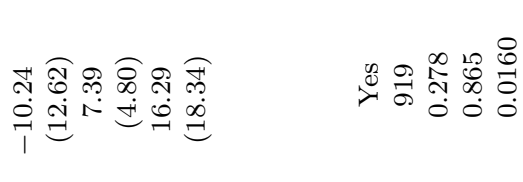 } & \\
\hline I্ & \multicolumn{5}{|c|}{ 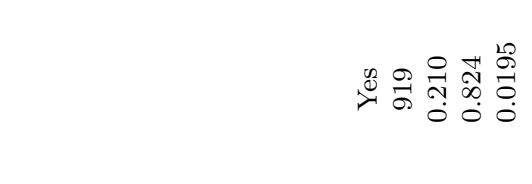 } & \\
\hline$\widehat{\infty} \underset{\sum}{\frac{\infty}{0}}$ & \multicolumn{5}{|c|}{ 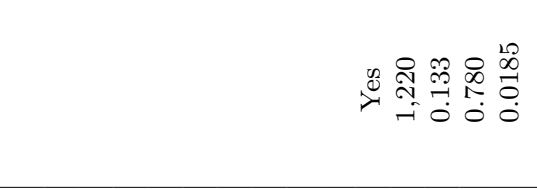 } & \\
\hline 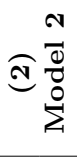 & \multicolumn{5}{|c|}{ 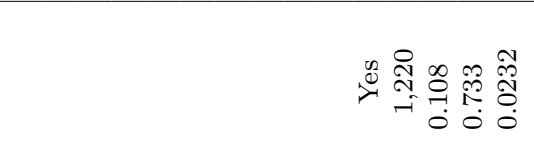 } & \\
\hline$\stackrel{\stackrel{-1}{\overrightarrow{0}}}{\stackrel{\overbrace{}}{0}}$ & \multirow[b]{2}{*}{ 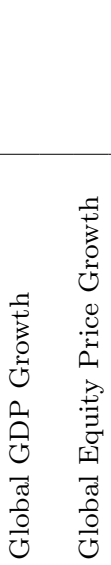 } & \multirow{2}{*}{\multicolumn{2}{|c|}{ 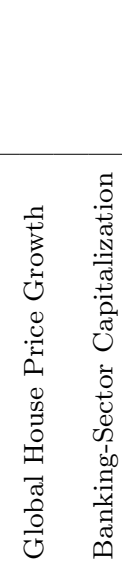 }} & & 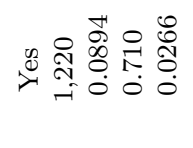 & \\
\hline & & & & 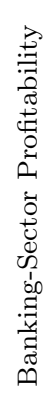 & 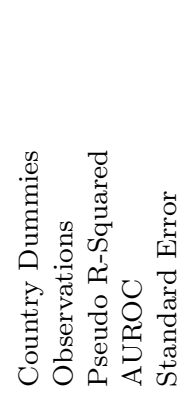 & \\
\hline
\end{tabular}


In order to compare the models' predictive abilities with those of the individual indicators, we once more apply the signaling approach by translating the predicted probabilities into country-specific percentiles and determining the optimal threshold for the issuance of warnings as the one that maximizes the relative usefulness of the model (see section 3.2). Table 5 shows that the relative usefulness of the domestic model is 0.236 , which is lower than that of the best individual indicators. However, the stepwise inclusion of the remaining variables improves the usefulness, so that model 3 surpasses the best domestic as well as the best global indicators in terms of relative usefulness. This indicates the benefits of a multivariate framework as compared with single indicators. We will elaborate more on these benefits by taking into account not only credit variables but also other variables that might affect the stability of the banking sector.

Models 4-7 provide the estimation results for the extended models. The sample size is somewhat smaller than in models $1-3$, as the data is not available for all variables across the whole period (see table 1). In order to make results comparable, model 4 reestimates model 3 on the reduced sample. The most striking difference between the two regressions is the coefficient for the domestic credit-to-GDP gap, which turns significant in the reduced sample. This indicates that any evaluation depends on the respective sample and should make policymakers cautious when generalizing findings from a particular sample of countries. However, the predictive abilities of the models are quite impressive. For example, model 5, which we refer to as our benchmark model, achieves 60.3 percent of the usefulness of a perfectly performing model and thus outperforms any individual indicator. The area under the ROC curve for this model is equal to 0.865 , indicating a good predictive ability of the model for a wide range of policymakers' preference parameters (see figure 3 for an illustration of the ROC curve for our benchmark model) 10

Overall, we find that the credit variables are indeed among the most important predictors of vulnerable states of the economy. However, both model fit and model performance increase significantly

\footnotetext{
${ }^{10}$ In contrast to the individual indicators and most of the credit models, the extended models perform well also for lower values of the preference parameter $\mu$, which we see as another advantage of these models. Results for other values of $\mu$ are available upon request.
} 


\begin{tabular}{|c|c|c|}
\hline$\ddot{\oplus}$ & 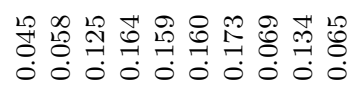 & \multirow{15}{*}{ 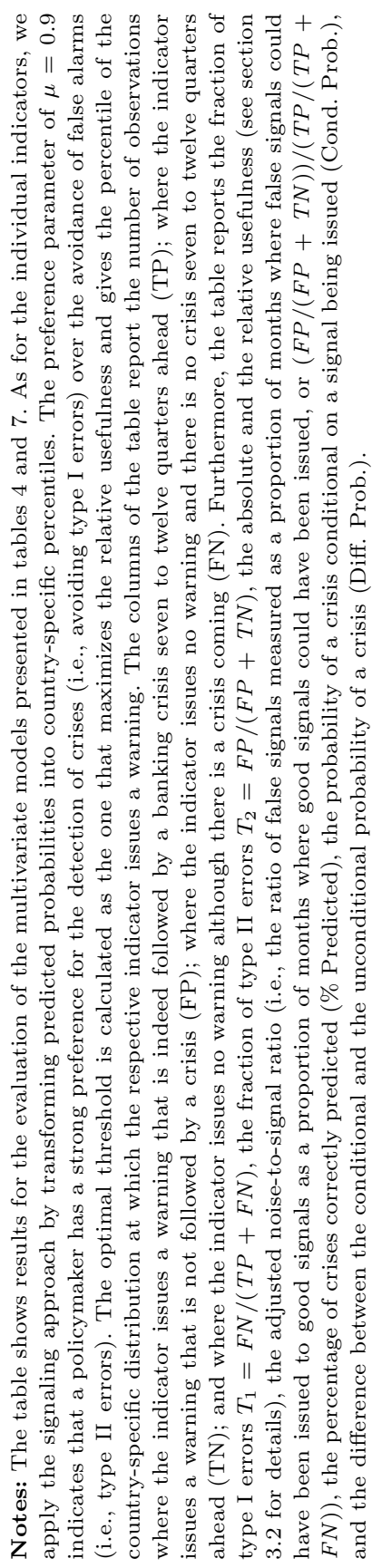 } \\
\hline $\begin{array}{l}\dot{0} \\
0\end{array}$ & 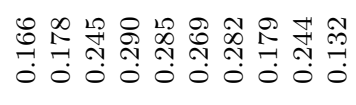 & \\
\hline 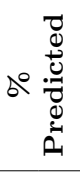 & 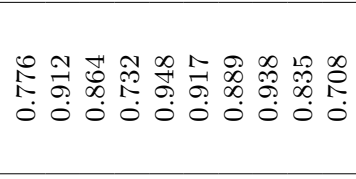 & \\
\hline 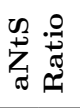 & 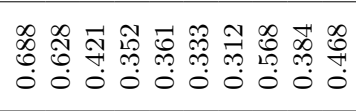 & \\
\hline 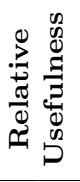 & 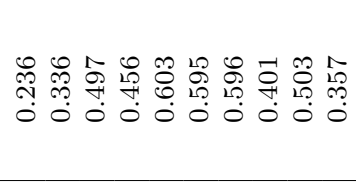 & \\
\hline 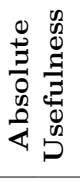 & 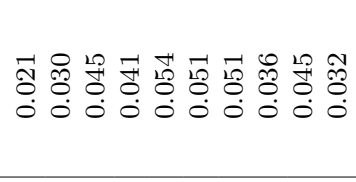 & \\
\hline$F^{N}$ & 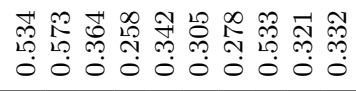 & \\
\hline$E^{-1}$ & 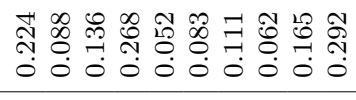 & \\
\hline$Z_{I}$ & 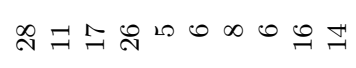 & \\
\hline $\mathrm{Z}_{\mathrm{H}}$ & 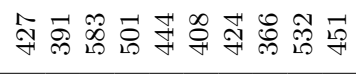 & \\
\hline$\frac{\rho}{x}$ & 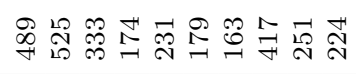 & \\
\hline $\mathrm{R}$ & 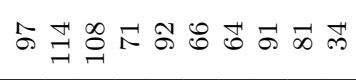 & \\
\hline$\frac{1}{D_{0}^{2}}$ & $\stackrel{\infty}{\rightarrow} \stackrel{F}{\sim}$ & \\
\hline$z$ & 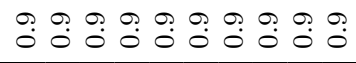 & \\
\hline & 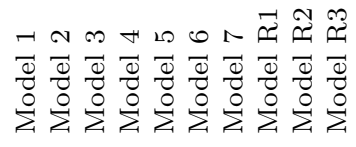 & \\
\hline
\end{tabular}




\section{Figure 3. ROC Curve for Benchmark Model (Model 5)}

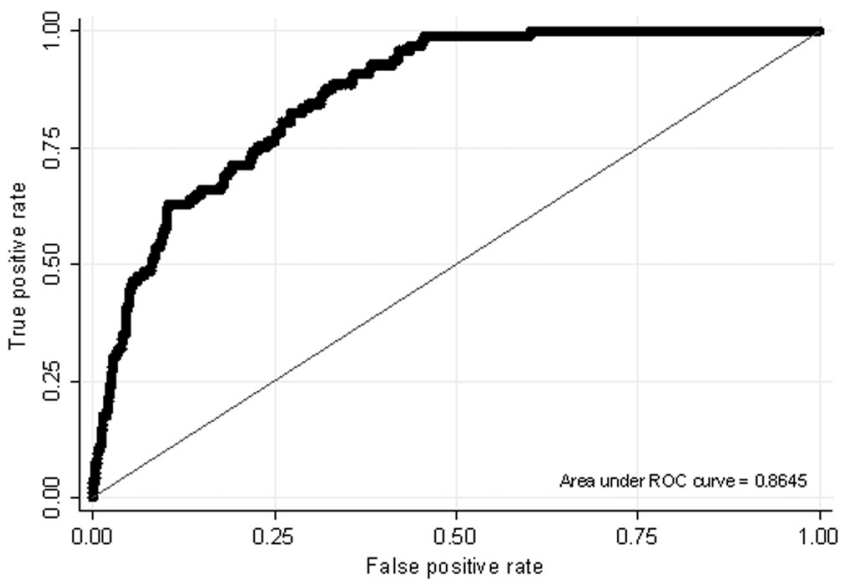

Notes: The figure shows the receiver operating characteristic (ROC) curve for our benchmark model. The area under the ROC curve (AUROC) is equal to 0.8645 .

when we include other macrofinancial indicators. For example, the consistently positive coefficient for house price growth indicates that asset price booms promote the buildup of vulnerabilities in the financial sector. This suggests that regulators should keep an eye on these developments instead of focusing exclusively on the development of credit variables. Moreover, model 7 shows that banking-sector variables exert a significant influence on the buildup of financial vulnerabilities. We make the following observations: First, a country is more likely to be in a vulnerable state when aggregate bank capitalization within the country is relatively low. This is a particularly important finding in the context of countercyclical capital buffers, as it indicates that indeed regulators could improve the resilience of the banking system by requiring banks to hold more capital when vulnerabilities build up. Second, we find that future banking crises are more likely when profits in the banking sector are relatively high. As Borio et al. (2010) point out, periods of high bank profitability are typically associated with rapid credit growth, increased risk-taking, and building up of vulnerabilities, which could explain the positive coefficient for the profitability variable preceding banking crises. 
Figure 4 illustrates the relationship between predicted crisis probabilities from our benchmark model (model 5) and actual banking-sector capitalization in the countries that had a banking crisis in 2007/08. Most countries exerted declining or constantly low

\section{Figure 4. Predicted Crisis Probabilities and Banking-Sector Capitalization}
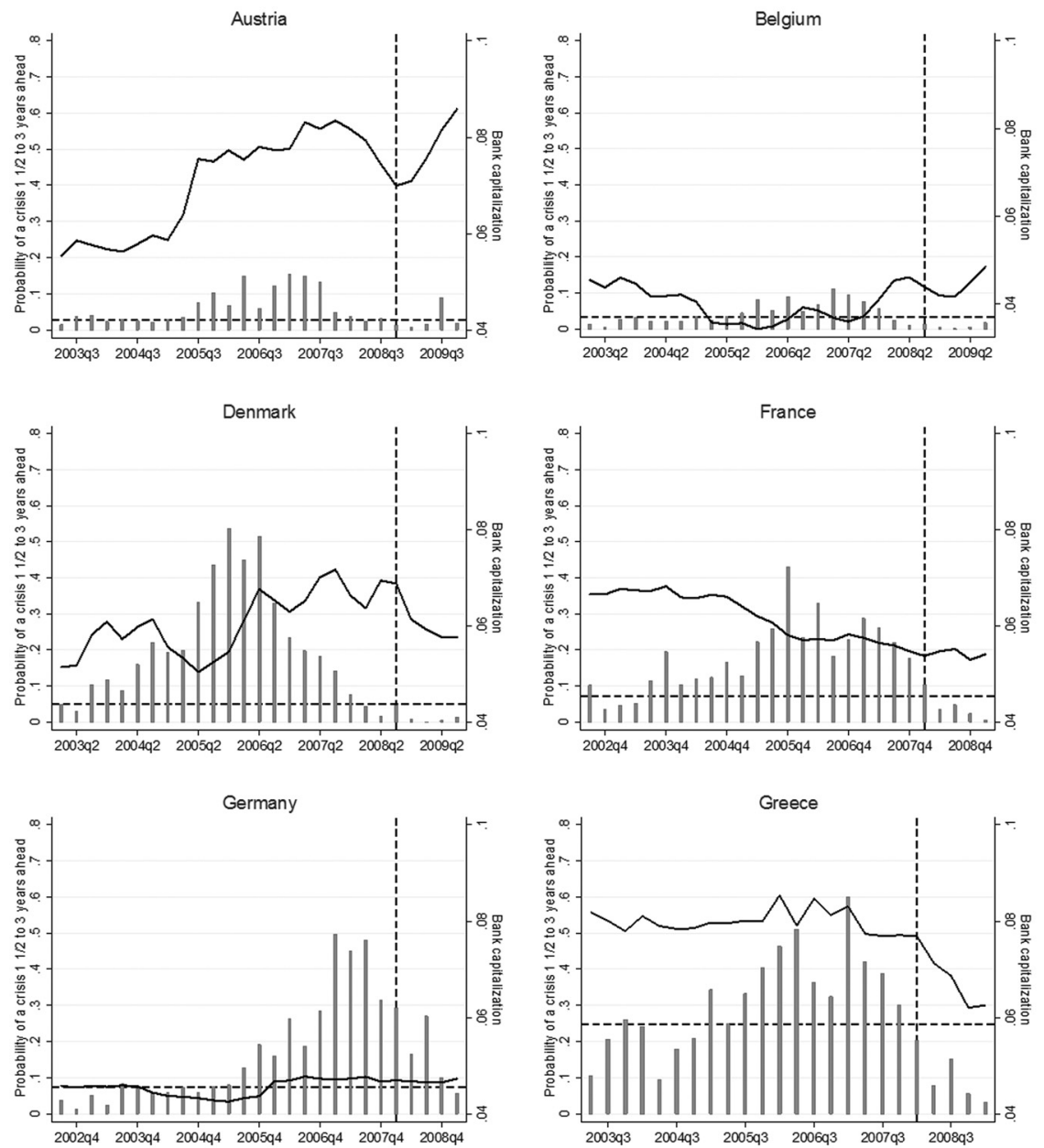

(continued) 


\section{Figure 4. (Continued)}
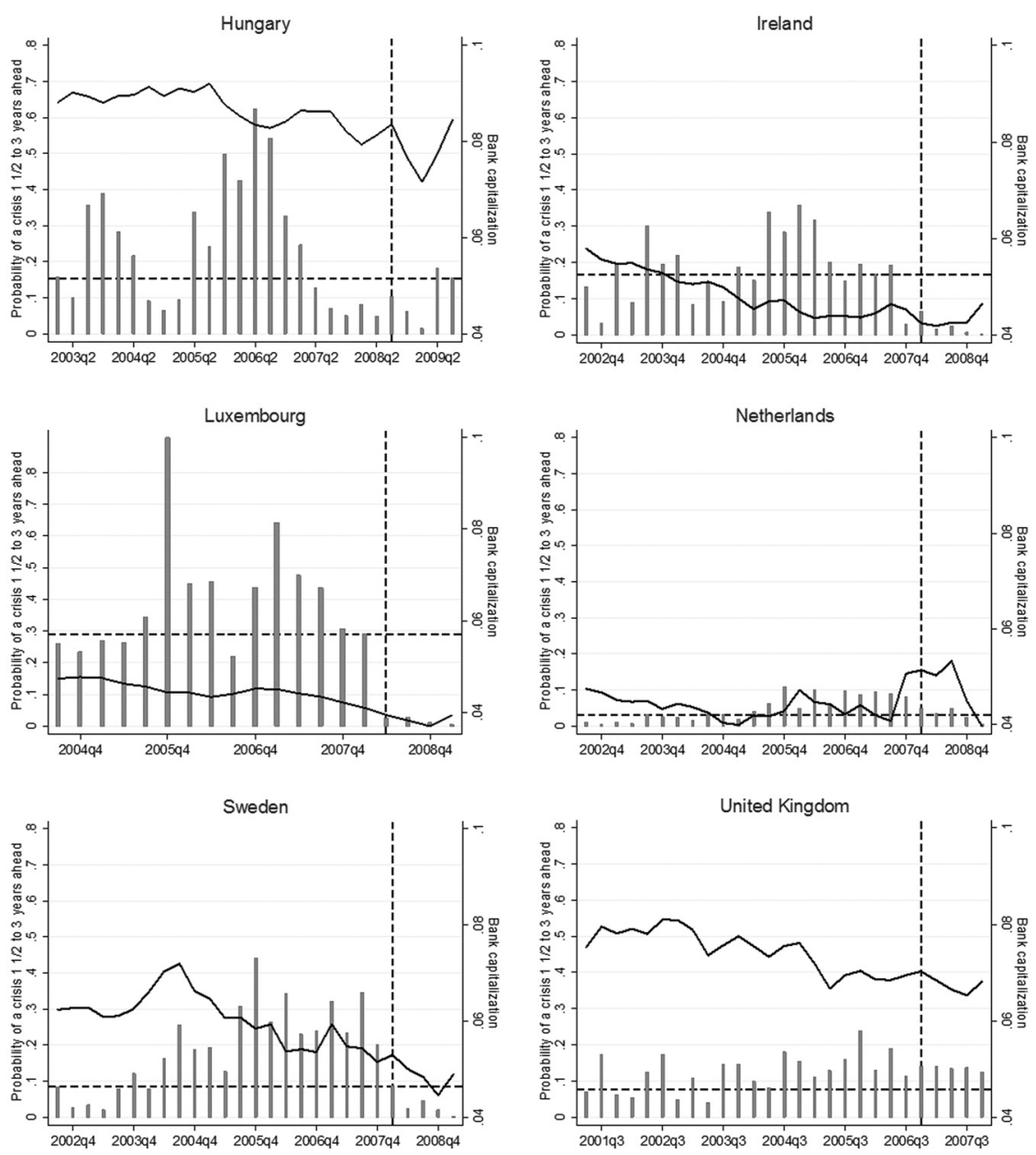

Notes: The figure plots the predicted probabilities (grey bars) from our benchmark model (model 5 in table 4) around the crises of 2008 in our sample countries (depicted by the dashed vertical lines). The optimal threshold for each country is depicted by the dashed horizontal line. The model issues a warning whenever the predicted probability is above this threshold. The black line shows the development of aggregate capitalization in the banking sector defined as total banking-sector equity over total banking-sector assets. 
levels of bank capitalization prior to the crisis, which is consistent with the evidence from model 7. A notable exception is Austria (and to some extent Denmark), where aggregate banking-sector capitalization actually increased prior to the crisis. At the same time, the benchmark model issues a warning already in late-2004/early-2005 in most cases. Hence, if they had relied on this signal, regulators would have had enough time for the activation of the CCyB prior to the crisis - even if we account for an announcement period of twelve months for the CCyB.

\subsection{Out-of-Sample Performance of the Models}

Given the objective of the early-warning systems, any assessment should focus on the out-of-sample performance. Moreover, as shown by, e.g., Berg, Borensztein, and Patillo (2005), successful in-sample predictions are much easier to achieve than successful out-of-sample predictions. In order to assess the out-of-sample usefulness of the models, we proceed as follows: First, we consecutively exclude countries that had a banking crisis prior to 2007 from the estimation of the benchmark model. Then, we test whether the model based on the remaining countries is able to predict the crises in the excluded ones 11

The results of this exercise are presented in figure 5 . The benchmark model signals the banking crises in the Nordic countries well before their onset in the early 1990s. In both Finland and Sweden, the indicator is consistently above the threshold from 1988:Q2 onwards, which is eleven quarters ahead of the crisis for Finland and nine quarters ahead for Sweden. In both cases, banks would have had enough time to build up capital before the crisis if the countercyclical capital buffer had been activated. Similarly, the model issues a warning signal for Italy from 1991:Q2 onwards, eleven quarters ahead of the crisis in 1994. In the United Kingdom, the crisis is relatively close

\footnotetext{
${ }^{11}$ In principle we could have tried to fit a model to the observations prior to 2007 in order to see whether this model would be able to predict the current crisis. However, as most of the crisis episodes in our sample occur after 2007, and as we particularly want to learn something from these episodes, we prefer the approach described above, i.e., we use the information from the current crisis and check whether it would have been useful for the prediction of past crises.
} 
Figure 5. Out-of-Sample Performance of the Model
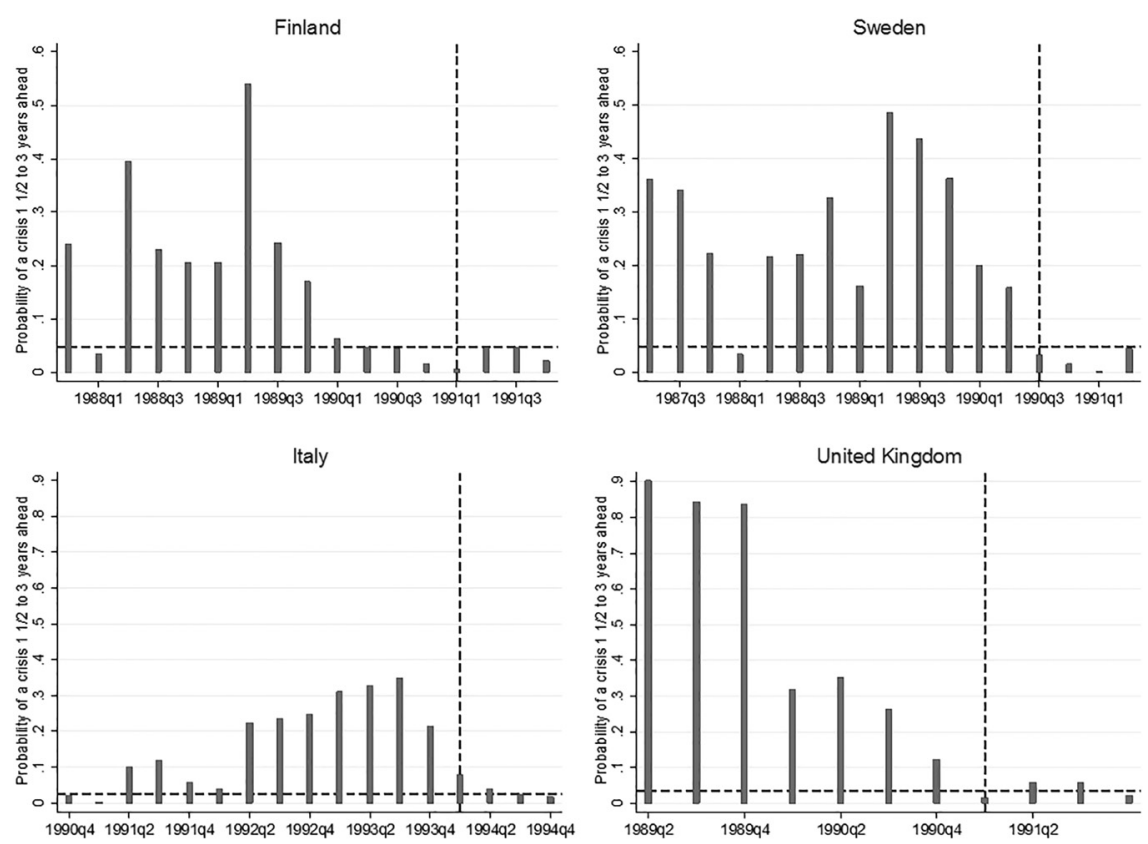

Notes: The figure shows results for an out-of-sample evaluation of our benchmark model (model 5 in table 4). We exclude the respective country from the estimation and depict the predicted probabilities (grey bars) from a model based on the remaining countries around the crisis in the excluded country (dashed vertical line). The model issues a warning whenever the predicted probability is higher than the optimal threshold within the country (dashed horizontal line).

to the beginning of the sample period. Yet, in those quarters preceding the crisis of 1991, the benchmark model consistently issues a warning signal. Overall, the benchmark model exhibits strong outof-sample properties. Information from the current crisis seems to be useful for the prediction of other systemic banking crises in the European Union.

\subsection{Robustness Checks}

In this section we modify the benchmark model (model 5 of table 4) in several ways in order to further assess the robustness of our results. The results from the robustness analysis are presented in tables 6 and 7 . 


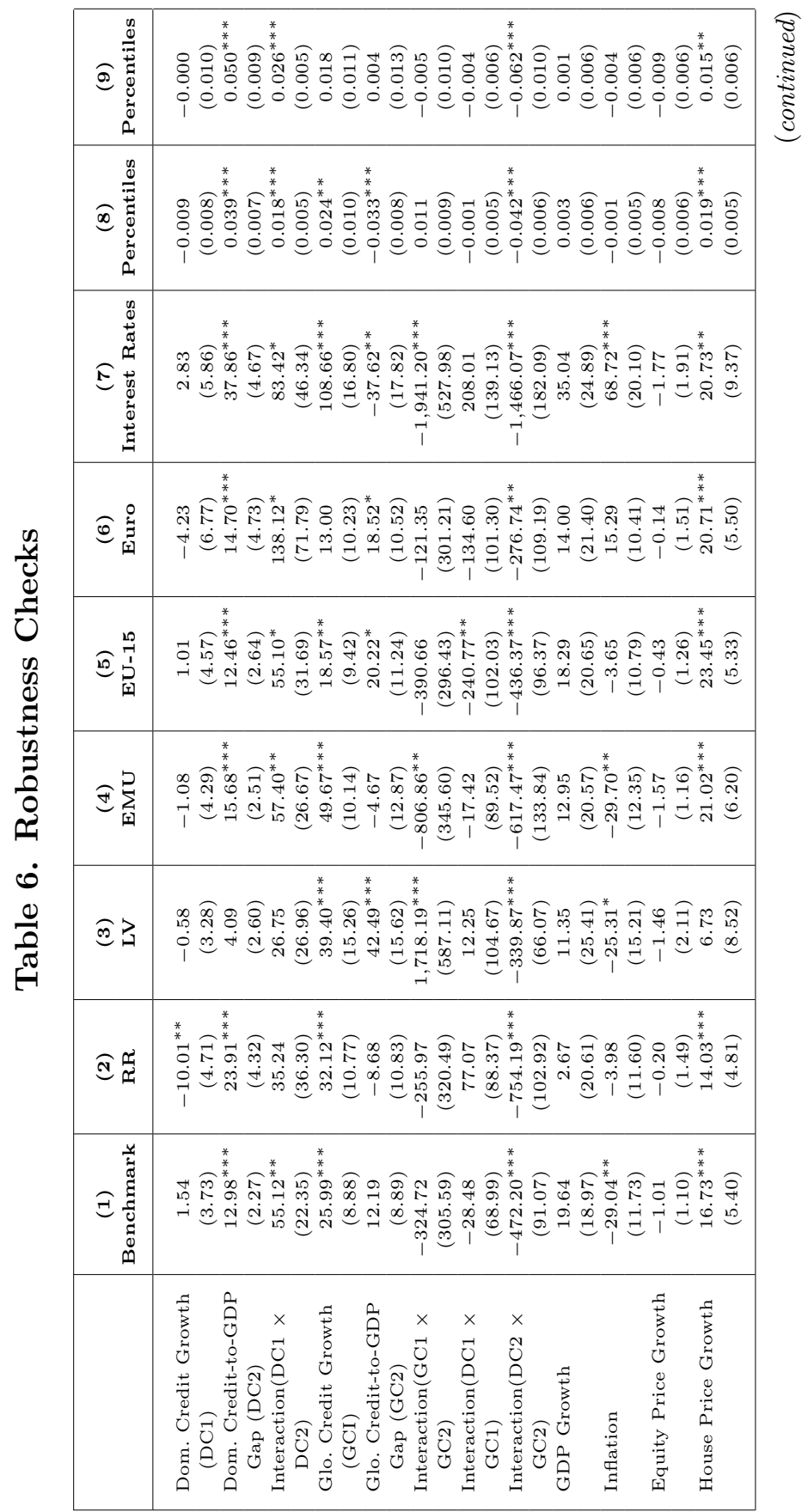




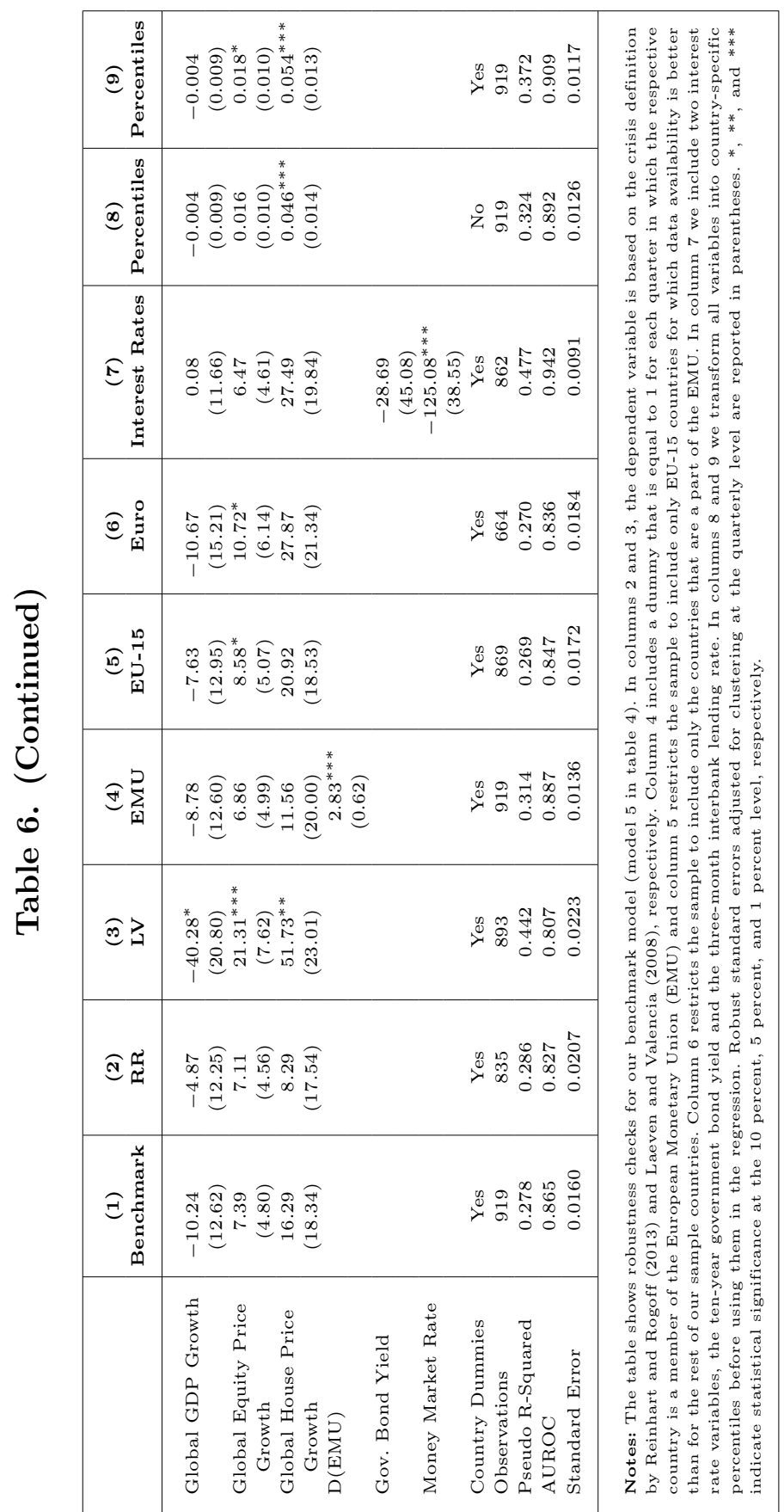




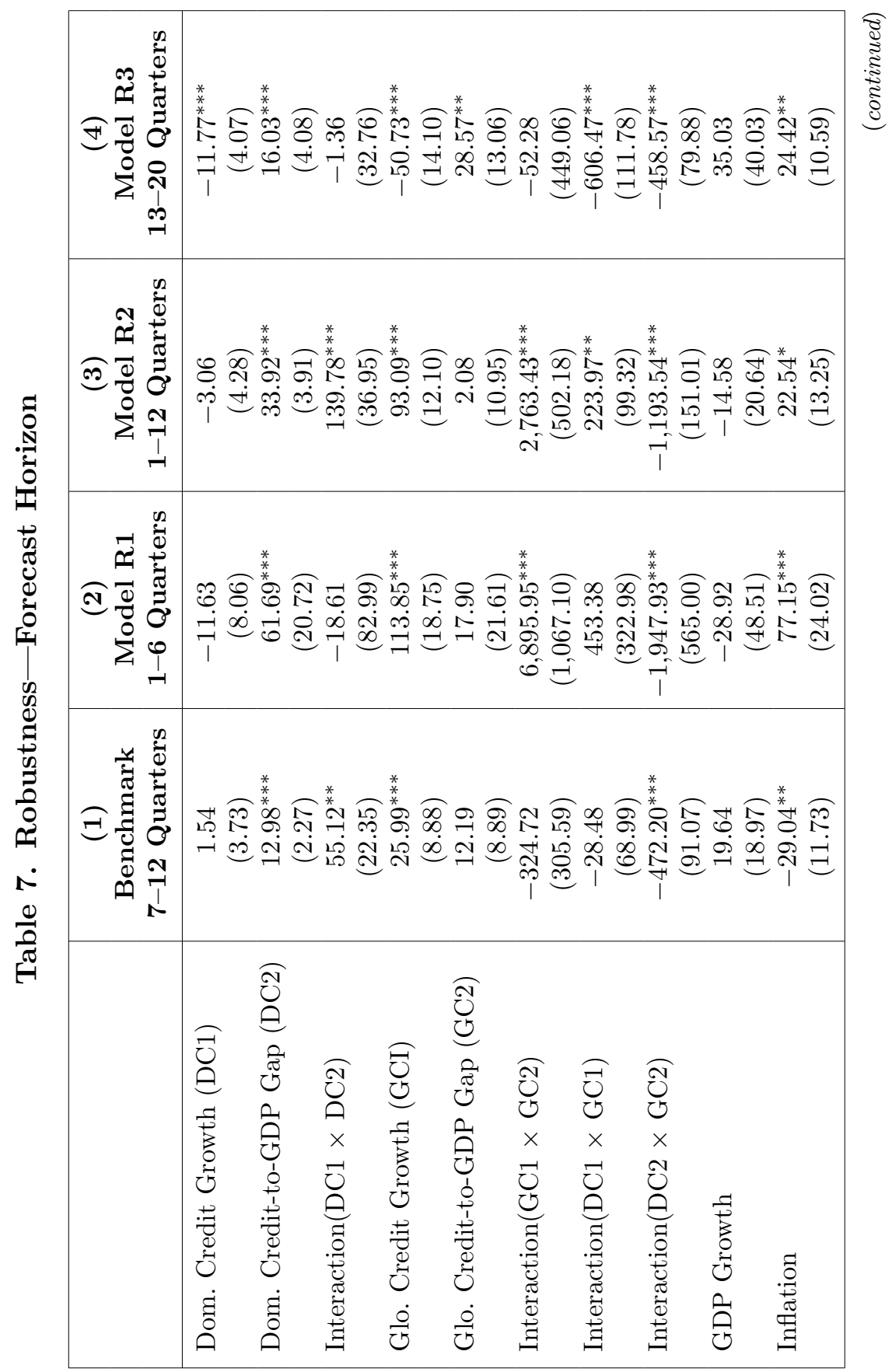




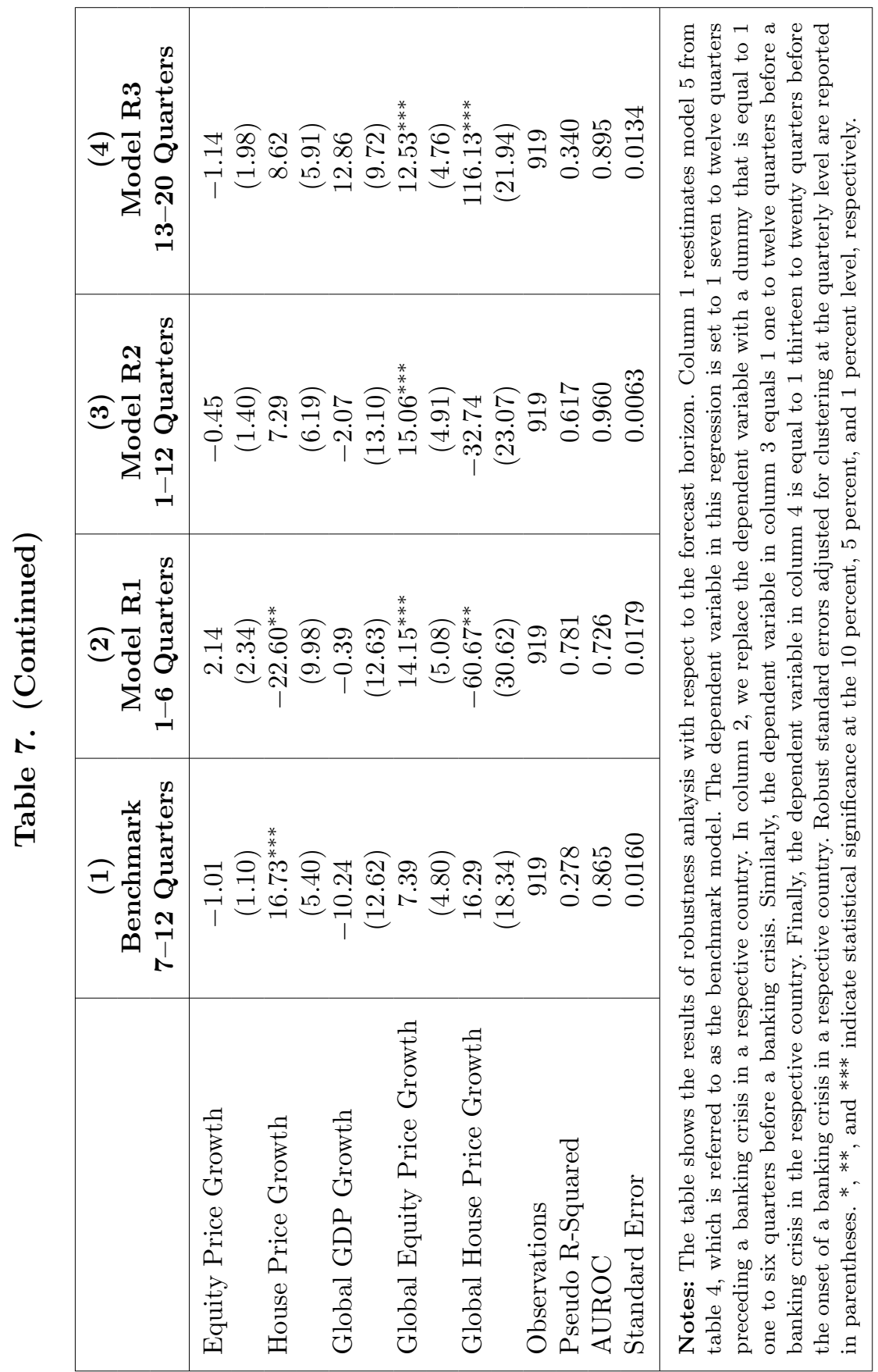


First, we check whether our results depend on the definition of the dependent variable. Apart from the ESCB Heads of Research database used in our analysis, the most common definitions of systemic banking crises are provided by Reinhart and Rogoff (2011) and Laeven and Valencia (2012). Although the various databases are broadly consistent with each other, there are some deviations in the timing of crises, as the definition of a systemic event in the banking sector requires a considerable amount of judgment. Columns 2 and 3 show that overall results are relatively similar for all three crisis definitions. Moreover, the area under the ROC curve is also greater than 0.8 for the other two models with the alternative crisis definitions, indicating good predictive abilities of the models.

Second, we include a dummy variable that is equal to 1 for each quarter in which the respective country is a member of the European Monetary Union (EMU). As expected, the coefficient for this dummy variable is positive and significant, as most crises in our sample occur after the establishment of the EMU in 1999 (see column 4). However, the coefficients of the other variables remain largely unaffected by the inclusion of this dummy variable. Furthermore, the results are robust if we restrict the sample to include only countries from the EU-15 (column 5) or only countries that are part of the EMU (column 6).

Third, we augment the model with a money market rate (column 7). The estimated negative coefficient is potentially related to the "great moderation," i.e., the general decline of inflation and money market rates over the sample period. The high R-squared and AUROC indicate that the fit of the model is superior to that of the other models. Despite this, we do not select this model as our benchmark model, as its out-of-sample forecast abilities are inferior to the benchmark model, potentially due to an overfitting problem.

Fourth, following Lo Duca and Peltonen (2013), we transform all variables into country-specific percentiles before using them in the regression. This method can be seen as an alternative way to account for heterogeneity across countries, as differences in levels of indicators between countries vanish for the transformed variables. Columns 8 and 9 show that most of the estimated coefficients have the same sign as in the benchmark model if we use this alternative method. 
Finally, we analyze model performance across different forecast horizons (see also Schudel 2013). Specifically, we check how the performance of the benchmark model and the indicator properties of variables change if the time window of the vulnerable state preceding a systemic banking crisis is altered from the seven to twelve quarters used in the standard specifications. Results in table 7 show that although the benchmark model is broadly robust to an alteration of the forecast horizon, the relative importance and the estimated signs of the coefficients tend to vary a bit. Particularly important are the reversed signs for domestic and global credit growth in the model with the thirteen- to twenty-quarters-ahead definition of a vulnerable state and the strong influence of global asset prices in this model (model R3). As shown in table 5, the benchmark model with a forecast horizon of seven to twelve quarters (model 5) provides the highest absolute and relative usefulness measures, followed by the model with a forecast horizon of one to twelve quarters (model R2). The performances of the models with the early (one to six quarters) and late (thirteen to twenty quarters) pre-crisis time horizons in terms of absolute and relative usefulness are broadly similar to, but markedly lower than, that of the benchmark model.

\section{Conclusion}

As a response to recent financial crises, the Basel III/CRD IV regulatory framework includes a countercyclical capital buffer $(\mathrm{CCyB})$ to increase the resilience of the banking sector and its ability to absorb shocks arising from financial and economic stress. In this context, this paper seeks to provide an early-warning model, which can be used to guide the buildup and release of capital in the banking sector. Given the prominence of private credit variables in the Basel III/CRD IV framework, the paper first examines the evolution of credit variables preceding banking crises in the EU member states and assesses their usefulness in guiding the setting of the CCyB. Furthermore, the paper examines the potential benefits of complementing private credit variables with other macrofinancial and banking-sector indicators in a multivariate logit framework. The evaluation of the policy usefulness of the credit indicators and models follows the methodology applied in Alessi and Detken (2011), Lo Duca and Peltonen (2013), and Sarlin (2013). 
The paper finds that, in addition to credit variables, other domestic and global financial factors such as equity and house prices and banking-sector variables help to predict macrofinancial vulnerabilities in EU member states. The importance of global variables in our models concurs with the view that excessive global liquidity is a key driver of financial vulnerabilities and highlights the importance of consistent cross-border and reciprocity arrangements, as in the European macroprudential framework. Furthermore, higher banking-sector capitalization decreases the probability of entering a vulnerable state, which provides a rationale for the implementation of countercyclical measures like the $\mathrm{CCyB}$. Moreover, future banking crises tend to be more likely when profits in the banking sector are relatively high, concurrent with the view that high bank profitability could be associated with rapid credit growth, increased risk-taking, and building up of vulnerabilities. Overall, our findings suggest that policymakers should take a broad approach in their analytical models supporting $\mathrm{CCyB}$ policy measures.

\section{Appendix. Data Sources and Technical Estimation Matters}

\section{Data Sources}

The individual series used in our paper stem from the following original sources: Data on total credit to the private non-financial sector are obtained from the BIS and-for those countries where BIS data is not available - from Eurostat. Information on nominal GDP growth and inflation rates comes from the IMF's International Financial Statistics (IFS). Data on stock prices are obtained from the OECD, while data on house prices are provided by the BIS. Banking-sector variables are obtained from two sources: The OECD provides relatively long series on banking-sector capitalization and profitability on an annual basis that we use in the empirical analysis. Additionally, for illustrative purposes, we use a shorter series of banking-sector capitalization in figure 4 that is available on a quarterly basis and that is obtained from the ECB's Balance Sheet Items (BSI) statistics. Finally, quarterly data on the ten-year government bond yield and the three-month interbank lending rate (money market rate) are obtained from the OECD. 


\section{Calculation of the Credit-to-GDP Gap}

Following the Basel Committee on Banking Supervision (2010), we use a backward-looking Hodrick-Prescott filter with a smoothing parameter $\lambda$ of 400,000 to calculate the credit-to-GDP gap. Recommendations in the BCBS Consultative Document are based on a paper by Borio et al. (2010), who find that trends calculated with a $\lambda$ of 400,000 perform well in picking up the long-term development of private credit. In particular, a $\lambda$ of 400,000 is consistent with the assumption of credit cycles being four times longer than business cycles if one follows a rule developed by Ravn and Uhlig (2002), which states that the optimal $\lambda$ of 1,600 for quarterly data should be adjusted by the fourth power of the observation frequency ratio (i.e., if credit cycles are four times longer than business cycles, $\lambda$ should be equal to $44 \times 1,600 \approx 400,000$ ).

\section{Receiver Operating Characteristics (ROC) Curves}

In addition to assessing the relative and absolute usefulness of a model, we also employ receiver operating characteristics (ROC) curves and the area under the ROC curve (AUROC) for comparing performance of the early-warning models. The ROC curve shows the tradeoff between the benefits and costs of a certain threshold $\tau$. When two models are compared, the better model has a higher benefit (TP rate $(T P R)$ on the vertical axis) at the same cost (FP rate $(F P R)$ on the horizontal axis) 12 Thus, as each FP rate is associated with a threshold, the measure shows performance over all thresholds or, equivalently, over all preference parameters of the policymaker. The AUROC is computed using trapezoidal approximations and measures the probability that a randomly chosen vulnerable state receives a higher predicted probability than a tranquil period. A perfect ranking has an AUROC equal to 1 , whereas a coin toss has an expected AUROC of 0.5 .

\footnotetext{
${ }^{12}$ The TPR (also called sensitivity) gives the ratio of periods where the model correctly issues a warning to all periods where a warning should have been issued, formally $T P R=T P=(T P+F N)$. The FPR (also called specificity) gives the ratio of periods where the model wrongly issues a signal to all periods where no signal should have been issued, formally $F P R=F P=(F P+T N)$. An ideal model would achieve a TPR of 1 (no missed crises) and an FPR of 0 (no false alarms).
} 


\section{References}

Ai, C., and E. C. Norton. 2003. "Interaction Terms in Logit and Probit Models." Economics Letters 80 (1): 123-29.

Alessi, L., A. Antunes, J. Babecky, S. Baltussen, M. Behn, D. Bonfim, O. Bush et al. 2015. "Comparing Different Early Warning Systems: Results from a Horse Race Competition among Members of the Macroprudential Research Network." MacroPrudential Research Network, European Central Bank.

Alessi, L., and C. Detken. 2011. "Quasi Real Time Early Warning Indicators for Costly Asset Price Boom/Bust Cycles: A Role for Global Liquidity." European Journal of Political Economy 27 (3): $520-33$.

2014. "Identifying Excessive Credit Growth and Leverage." ECB Working Paper No. 1723.

Allen, F., and D. Gale. 2009. Understanding Financial Crises. Oxford University Press.

Babecky, J., T. Havranek, J. Mateju, M. Rusnák, K. Smidkova, and B. Vasicek. 2014. "Banking, Debt, and Currency Crises in Developed Countries: Stylized Facts and Early Warning Indicators." Journal of Financial Stability 15 (December): 1-17.

Barrell, R., E. P. Davis, D. Karim, and I. Liadze. 2010. "Bank Regulation, Property Prices and Early Warning Systems for Banking Crises in OECD countries." Journal of Banking and Finance 34 (9): 2255-64.

Basel Committee on Banking Supervision. 2010. "Guidance for

National Authorities Operating the Countercyclical Capital Buffer." Bank for International Settlements.

Behn, M., C. Detken, T. Peltonen, and W. Schudel. 2013. "Setting Countercyclical Capital Buffers based on Early Warning Models: Would It Work?" ECB Working Paper No. 1604.

Berg, A., E. Borensztein, and C. Patillo. 2005. "Assessing Early Warning Systems: How Have They Worked in Practice?" IMF Staff Papers 52 (3): 462-502.

Borio, C., M. Drehmann, L. Gambacorta, G. Jimenez, and C. Trucharte. 2010. "Countercyclical Capital Buffers: Exploring Options." BIS Working Paper No. 317.

Brunnermeier, M., and M. Oehmke. 2013. "Bubbles, Financial Crises, and Systemic Risk." In Handbook of the Economics of 
Finance, Vol. 2, Part B, ed. G. M. Constantinides, M. Harris, and R. M. Stulz, 1221-88 (chapter 18). Elsevier.

Bussière, M., and M. Fratzscher. 2006. "Towards a New Early Warning System of Financial Crises." Journal of International Money and Finance 25 (6): 953-73.

Caprio, G., and D. Klingebiel. 2003. "Episodes of Systemic and Borderline Financial Crises." World Bank Research Dataset.

Castro, C., A. Estrada, and J. Martínez-Pagés. 2016. "The Countercyclical Capital Buffer in Spain: An Analysis of Key Guiding Indicators." Working Paper No. 1601, Banco de Espana.

Committee on the Global Financial System. 2011. "Global Liquidity - Concept, Measurement and Policy Implications." CGFS Paper No. 45, Bank for International Settlements.

Dembiermont, C., M. Drehmann, and S. Muksakunratana. 2013. "How Much Does the Private Sector Really Borrow? A New Database for Total Credit to the Private Non-financial Sector." BIS Quarterly Review (March): 65-81.

Demirgüç-Kunt, A., and E. Detragiache. 1998. "The Determinants of Banking Crises in Developing and Developed Countries." IMF Staff Papers 45 (1): 81-109.

- 2000. "Monitoring Banking Sector Fragility. A Multivariate Logit Approach." World Bank Economic Review 14 (2): 287-307. Detragiache, E., and A. Spilimbergo. 2001. "Crises and Liquidity: Evidence and Interpretation." IMF Working Paper No. 01/2.

Dickey, D. A., and W. A. Fuller. 1979. "Distribution of the Estimators for Autoregressive Time Series with a Unit Root." Journal of the American Statistical Association 74 (366a): 427-31.

Drehmann, M., C. Borio, and K. Tsatsaronis. 2011. "Anchoring Countercyclical Capital Buffers: The Role of Credit Aggregates." International Journal of Central Banking 7 (4): 189-240.

- 2013. "Evaluating Early Warning Indicators of Banking Crises: Satisfying Policy Requirements." BIS Working Paper No. 421.

Drehmann, M., and M. Juselius. 2014. "Evaluating Early Warning Indicators of Banking Crises: Satisfying Policy Requirements." International Journal of Forecasting 30 (3): 759-80. 
Edge, R. M., and R. R. Meisenzahl. 2011. "The Unreliability of Credit-to-GDP Ratio Gaps in Real Time: Implications for Countercyclical Capital Buffers." International Journal of Central Banking 7 (4): 261-98.

Ferrari, S., and M. Pirovano. 2015. "Early Warning Indicators for Banking Crises: A Conditional Moments Approach."

Frankel, J. A., and A. K. Rose. 1996. "Currency Crashes in Emerging Markets: An Empirical Treatment." Journal of International Economics 41 (3-4): 351-66.

Galati, G., I. Hindrayanto, S. J. Koopman, and M. Vlekke. 2016. "Measuring Financial Cycles in a Model-based Analysis: Empirical Evidence for the United States and the Euro Area." Economics Letters 145 (August): 83-87.

Hanschel, E., and P. Monnin. 2005. "Measuring and Forecasting Stress in the Banking Sector: Evidence from Switzerland." BIS Papers 22 (April): 431-49.

Holopainen, M., and P. Sarlin. 2016. "Toward Robust Early-Warning Models: A Horse Race, Ensembles and Model Uncertainty.” ECB Working Paper No. 1900.

Im, K. S., M. H. Pesaran, and Y. Shin. 2003. "Testing for Unit Roots in Heterogeneous Panels." Journal of Econometrics 115 (1): $53-74$.

International Monetary Fund. 2013. "Global Liquidity — Credit and Funding Indicators." IMF Policy Paper (July).

Ito, Y., T. Kitamura, K. Nakamura, and T. Nakazawa. 2014. "New Financial Activity Indexes: Early Warning System for Financial Imbalances in Japan." Working Paper No. 14-E-7, Bank of Japan.

Jordà, Ò., M. Schularick, and A. Taylor. 2015. "Leveraged Bubbles." Journal of Monetary Economics 76 (Supplement): S1-S20.

Kaminsky, G., S. Lizondo, and C. M. Reinhart. 1998. "Leading Indicators of Currency Crises." IMF Staff Papers 45 (1): 1-48.

Kaminsky, G. L. 2006. "Currency Crises: Are They All the Same?" Journal of International Money and Finance 25 (3): 503-27.

Kaminsky, G. L., and C. M. Reinhart. 1999. "The Twin Crises: The Causes of Banking and Balance-of-Payments Problems." American Economic Review 89 (3): 473-500. 
Karim, D., I. Liadze, R. Barrell, and P. Davis. 2013. "Off-balance Sheet Exposures and Banking Crises in OECD Countries." Journal of Financial Stability 9 (4): 673-81.

Laeven, L., and F. Valencia. 2008. "Systemic Banking Crises: A New Database." IMF Working Paper No. 08/224.

2010. "Resolution of Banking Crises: The Good, the Bad, and the Ugly." IMF Working Papers No. 10/146.

- 2012. "Systemic Banking Crises Database: An Update." IMF Working Paper No. 12/163.

Little, T. D., J. A. Bovaird, and K. F. Widaman. 2006. "On the Merits of Orthogonalizing Powered and Product Terms: Implications for Modeling Interactions among Latent Variables." Structural Equation Modeling 13 (4): 497-519.

Lo Duca, M., and T. Peltonen. 2013. "Assessing Systemic Risks and Predicting Systemic Events." Journal of Banking and Finance 37 (7): 2183-95.

López-Salido, D., J. Stein, and E. Zakrajŝek. 2016. "Credit-Market Sentiment and the Business Cycle." NBER Working Paper No. 21879.

Manasse, P., R. Savona, and M. Vezzoli. 2016. "Danger Zones for Banking Crises in Emerging Markets." International Journal of Finance and Economics 21 (4): 360-81.

Park, J. Y., and P. C. Phillips. 2000. "Nonstationary Binary Choice." Econometrica 68 (5): 1249-80.

Ravn, M. O., and H. Uhlig. 2002. "On Adjusting the HodrickPrescott Filter for the Frequency of Observations." Review of Economics and Statistics 84 (2): 371-76.

Reinhart, C. M., and K. S. Rogoff. 2011. "From Financial Crash to

Debt Crisis." American Economic Review 101 (5): 1676-1706.

- 2013. "Banking Crises: An Equal Opportunity Menace." Journal of Banking and Finance 37 (11): 4557-73.

Repullo, R., and J. Saurina. 2011. "The Countercyclical Capital Buffer of Basel III: A Critical Assessment." CEPR Discussion Paper No. DP8304.

Sarlin, P. 2013. "On Policymakers' Loss Functions and the Evaluation of Early Warning Systems." Economics Letters 119 (1): $1-7$. 
Schudel, W. 2013. "Shifting Horizons: Assessing Macro Trends Before, During, and Following Systemic Banking Crises." ECB Working Paper No. 1766.

Schularick, M., and A. M. Taylor. 2012. "Credit Booms Gone Bust: Monetary Policy, Leverage Cycles, and Financial Crises, 18702008." American Economic Review 102 (2): 1029-69.

Schüler, Y., P. Hiebert, and T. Peltonen. 2015. "Characterising the Financial Cycle: A Multivariate and Time-varying Approach." ECB Working Paper No. 1846.

- 2017. "Coherent Financial Cycles for G-7 Countries: Why Extending Credit Can Be an Asset." ESRB Working Paper No. 43.

Seidler, J., and A. Gersl. 2011. "Credit Growth and Capital Buffers: Empirical Evidence from Central and Eastern European Countries." Research and Policy Note No. 2/2011, Czech National Bank.

Yeyati, E. L., and U. Panizza. 2011. "The Elusive Costs of Sovereign Defaults." Journal of Development Economics 94 (1): 95-105. 